\title{
ANALISIS TEGANGAN PIPA PADA SISTEM INSTALASI PERPIPAAN GEOTHERMAL DI PROYEK X
}

\author{
Ahmad Husen ${ }^{1}$, Nur Cholis ${ }^{2}$, Akbar Nur Setiadi ${ }^{3}$ \\ Program Studi Teknik Mesin, Institut Sains dan Teknologi Nasional, Jakarta Selatan ${ }^{1} 3$ \\ Program Studi Teknik Mesin, Universitas Pembangunan Nasional “Veteran” Jakarta, Jakarta Selatan ${ }^{2}$ \\ email $^{1}$ : akbarns1994@gmail.com
}

\begin{abstract}
Piping system is a complex system, at the time of designing many aspects that need to be considered so as to obtain a design of good and efficient piping system. In this thesis will be discussed about pipeline system stress analysis in project $x$ with line number 0C27LBA01-14"AD20 BR001, OC27LBA01-14"-AA20 BR005 and 0CSGLBA01-18”-AA20 BR001 in which the fluid flowing in the pipe fluctuates at the daily pressure and temperature and a stress calculation analysis is required to ensure that the installed pipe line and pipe support are positioned in place so that the stress does not exceed the maximum limitation of the stress set by the ASME code B31.1. the result of stress calculation analysis due to the maximum sustain load is at node 180 in the CAESAR II program $564,2 \mathrm{Kg} / \mathrm{cm}^{2}$ and manual calculation $327,3 \mathrm{Kg} / \mathrm{cm}^{2}$ with a calculation deviation of 41,99\%. For calculation of the stress due to the maximum expansion load is at node 149 in the CAESAR II program 1079,3 Kg/cm ${ }^{2}$ and manual calculation $791,98 \mathrm{Kg} / \mathrm{cm}^{2}$ with a calculation deviation of $26,71 \%$. The value of sustain load and expansion load with two calculation methods none of which exceed the limit of the allowable stress on ASME B31.1, and due to fluid fluctuation in terms of pressure and temperature that cause the pipe to undergo erratic changes every day, the node 180 needs to be installed more flexible support so it can follow the change of the pipe, so it can be concluded that the piping system $x$ projected did not happen overstress and safe to operate
\end{abstract}

Keywords: Sustain, Ekspansi, Code/Standar, Piping system, stress analysis, ASME B31.1.

\section{PENDAHULUAN}

\section{Latar Belakang Masalah}

Dalam sebuah kegiatan Industri khususnya

industri Panas Bumi (Geothermal) keterkaitan antara satu subsistem dengan subsistem lainnya menjadi suatu hal yang sangat utama, karena dari subsistem tersebut akan membentuk suatu sistem baku yang dapat menunjang keberhasilan dari suatu kegiatan industri Panas Bumi. Apabila terjadi perubahan pada satu subsistem maka secara otomatis akan mempengaruhi terhadap subsistem yang lainnya sehingga proses kegiatan industri akan mengalami gangguan.

Dalam dunia industri Panas Bumi (Geothermal) salah satu subsistem yang ada adalah jalur perpipaan, dimana jalur perpipaan ini merupakan suatu jalur utama yang mengalirkan fluida baik berupa cairan atau gas dan mendistribusikannya dari area cluster ke power station dimana area cluster adalah area sumber sumurnya dan area power station adalah area yang mengelolah panas bumi menjadi listrik. Sistem perpipan harus mampu menahan beban yang bekerja, baik itu beban statik dan dinamik.
Proyek Panas Bumi (Geothermal), merupakan proyek yang mempunyai sistem perpipaan yang kompleks, karena proyek ini terdapat banyak sistem perpipaan yang termasuk jalur pipa kritis (critical pipe line). Jalur pipa kritis yaitu jalur perpipaan yang mengalami tegangan yang melebihi kekuatan izin material. Penyebab timbulnya daerah kritis ini antara lain karena diameter pipa yang besar, fluida kerja bersuhu dan bertekanan tinggi. Efek yang dapat timbul pada jalur kritis akan terjadi kegagalan pada material.

Permasalahan yang terjadi pada skripsi ini adalah fluida yang mengalir pada pipa mengalami fluktuasi pada pressure dan temperatur setiap harinya sehingga menyebabkan tegangan dipipa tersebut berlebih (overstress). Untuk mengatasi permasalahan ini perlu dilakukan analisa tegangan pipa dan juga menambahkan atau menggeser penyangga pada pipa tersebut agar sistem perpipaan aman pada saat kondisi operasi.

\section{Perumusan Masalah}

Dalam penelitian ini penulis merumuskan masalah sebagai berikut: 
1. Terjadi getaran berlebih pada sistem perpipaan di sisi tekan pompa P-003E sehingga diperlukan analisis apakah sistem perpipaan itu aman atau tidak untuk beroperasi.

2. Terjadi overstress pada sistem perpipaan di sisi tekan pompa P-003E akibat beban Sustain dan beban Ekspansi, sehingga diperlukan penambahan berupa penyangga pada jalur pipa itu.

\section{Batasan Masalah}

Dalam penelitian ini penulis membatasi masalah sebagai berikut:

1. Perhitungan overstress pada sistem perpipaan mengacu pada standar ASME B31.1.

2. Penyesuaian desain sistem perpipaan geothermal berdasarkan muai panas yang dialami pipa saat dialiri fluida Two Phase.

3. Perhitungan hanya dilakukan pada line number 0C27LBA01-14"-AD20 BR001, 0C27LBA0114”-AA20 BR005 dan 0CSGLBA01-18”-AA20 BR001.

4. Perhitungan hanya dilakukan pada area cluster atau station pada proyek $\mathrm{X}$ yang berada di kota Lampung.

5. Perhitungan analisa sistem perpipaan ini dilakukan dengan menggunakan program CAESAR II 2014 versi 7.0, sehingga didapat hasil perhitungan gaya, momen, tegangan dan panjang ekspansi pipa pada jalur perpipaan dalam bentuk angka yang dapat ditabelkan.

\section{Maksud dan Tujuan}

Dari latar belakang dan perumusan masalah yang telah penulis sampaikan maka dimaksudkan:

1. Memberikan manfaat berupa upaya perbaikan untuk mengantisipasi dan mengurangi terjadinya overstress pada sistem perpipaan.

2. Memahami dan mengerti tentang standard ASME B31.1 yang digunakan untuk merancang dan menganalisa sistem perpipaan.

Sedangkan tujuan dari penelitian sebagai berikut:

1. Menganalisis seberapa besar tingkat overstress pada sistem perpipaan akibat beban sustained dan expansion agar tegangan didalam pipa tetap dalam batasan ASME B31.1.

2. Memastikan penyangga/support yang telah ditambahkan bisa mengurangi tegangan pada sistem perpipaan akibat fluktuasi fluida.

3. Dapat memastikan bahwa jalur pipa tersebut aman dan apabila ada tegangan yang kritis dapat memberikan solusi yang terbaik sehingga tegangan yang berlebih dapat dicegah.

\section{TINJAUAN PUSTAKA}

\section{Teori Dasar Tegangan Pipa}

Dalam menerapkan kode standar desain, kita harus mengerti prinsip dasar dari tegangan pipa dan halhal yang berhubungan dengannya. Sebuah pipa dinyatakan rusak jika tegangan dalam yang terjadi pada pipa melebihi tegangan batas material yang diizinkan. Dari definisi yang sederhana ini ada dua buah istilah yang harus dipahami dengan benar yaitu tegangan dalam pipa dan tegangan batas yang diizinkan. (Agustinus, 2009)

Tegangan dalam yang terjadi pada pipa di sebabkan oleh tekanan dari dalam pipa, beban luar seperti berat mati dan pemuaian thermal, dan bergantung pada bentuk geometri pipa serta jenis material pipa. Sedangkan tegangan batas lebih banyak di tentukan oleh jenis material dan metode produksinya.

Dalam pembahasan kode standar ini kita harus membedakan pengertian tegangan pipa menjadi:

1. Tegangan pipa aktual, yaitu tegangan hasil pengukuran dengan strain gauge atau perhitungan analisis secara manual maupun dengan piranti lunak komputer.

2. Tegangan pipa kode, yaitu tegangan hasil perhitungan dengan menggunakan persaman tegangan yang tertera dalam kode standar tertentu.

Tegangan adalah besaran vektor yang selain memiliki nilai juga memerlukan arah. Nilai dari tegangan di definisikan sebagai gaya $(F)$ per satuan luas $(A)$. Untuk mendefinisikan arah pada tegangan pipa, sebuah sumbu prinsip pipa di buat saling tegak lurus seperti yang ditunjukkan pada Gambar 1 di bawah ini:

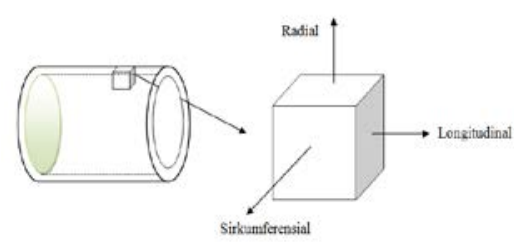

Gambar 1. Arah pada tegangan pipa (Sumber: Jamaludin, Achmad, Jurnal 2016, Analisis Tegangan Sistem Perpipaan Pada Sisi Tekan Pompa P003E Menggunakan Caesar II dan Perhitungan Manual, hal 5)

Sumbu terletak di bidang tengah dinding pipa dan yang salah satu arahnya sejajar dengan panjang pipa disebut sumbu aksial atau longitudinal. Sumbu yang tegak lurus terhadap dinding pipa dengan arahnya bergerak dari pusat pipa menuju luar pipa disebut sumbu radial. Sumbu yang sejajar dengan dinding pipa tetapi tegak lurus dengan sumbu aksial disebut sumbu tangensial atau sirkumferensial. 


\subsection{Ragam Tegangan}

Tegangan yang tejadi dalam sistem perpipaan dapat dikelompokkan ke dalam dua kategori, yakni Tegangan Normal (Normal Stress) dan Tegangan Geser (Shear Stress).

Tegangan normal terdiri dari tiga komponen tegangan, yang masing-masing adalah:

1. Tegangan Longitudinal (Longitudinal Stress), yaitu tegangan yang searah panjang pipa.

2. Tegangan Tangensial atau Tegangan Keliling (Circumferential Stress atau Hoop Stress), yaitu tegangan yang searah garis singgung penampang pipa,

3. Tegangan Radial (Radial Stress), yaitu tegangan searah jari-jari penampang pipa.

Tegangan Geser terdiri dari dua komponen tegangan, yang masing-masing adalah:

1. Tegangan Geser (Shear Stress), yaitu tegangan akibat gaya geser,

2. Tegangan Puntir atau Tegangan Torsi (Torsional Stress), yaitu tegangan akibat momen puntir pada pipa.

\subsubsection{Tegangan Longitudinal}

Tegangan longitudinal $\left(S_{L}\right)$ atau tegangan aksial adalah tegangan yang arahnya sejajar dengan sumbu longitudinal. Nilai tegangan ini akan dinyatakan positif jika tegangan yang terjadi adalah tegangan tarik dan negatif jika tegangannya berupa tegangan tekan. Tegangan Longitudinal merupakan jumlah dari Tegangan Aksial (Axial Stress), Tegangan Tekuk (Bending Stress) dan Tegangan Tekanan (Pressure Stress). Mengenai ketiga tegangan ini dapat diuraikan berikut ini.

1. Tegangan Aksial $\left(S_{a x}\right)$ adalah tegangan yang ditimbulkan oleh gaya $F_{a x}$ yang bekerja searah dengan sumbu pipa seperti terlihat pada Gambar 2. Nilai dari tegangan aksial dapat dirumuskan sebagai berikut.

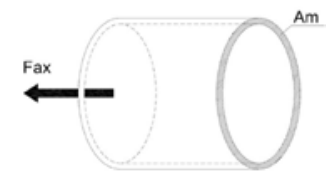

Gambar 2. Tegangan aksial

(Sumber: Jamaludin, Achmad, Jurnal 2016, Analisis Tegangan Sistem Perpipaan Pada Sisi Tekan Pompa P003E Menggunakan Caesar II dan Perhitungan Manual, hal 7)

$$
S_{a x}=\frac{F_{a x}}{A_{m}}=\frac{P \cdot A_{i}}{\pi \cdot d_{m} \cdot t}=\frac{P \cdot A_{i}}{\frac{\pi}{4}\left(d_{o}{ }^{2}-d_{i}{ }^{2}\right)}
$$

2. Tegangan Tekuk $\left(S_{B}\right)$ adalah tegangan yang ditimbulkan oleh momen $(M)$ yang bekerja diujung-ujung pipa. Tegangan tekuk maksimum terjadi pada permukaan pipa sedangkan tegangan minimum terjadi pada sumbu pipa seperti terlihat pada Gambar 3. Nilai dari tegangan tersebut dapat dirumuskan sebagai berikut.

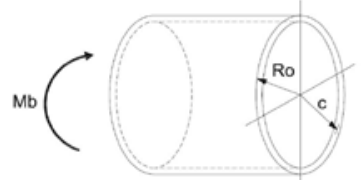

Gambar 3. Tegangan Tekuk

(Sumber: Jamaludin, Achmad, Jurnal 2016, Analisis Tegangan Sistem Perpipaan Pada Sisi Tekan Pompa P003E Menggunakan Caesar II dan Perhitungan Manual, hal 7)

$$
S_{B}=\frac{M_{b} \cdot C}{I}=\frac{M_{b} \cdot R_{o}}{I}=\frac{M_{b}}{Z}
$$

3. Tegangan Tekan $\left(S_{P}\right)$ adalah tegangan yang ditimbulkan oleh gaya tekan internal $(P)$ yang bekerja pada dinding pipa dan searah sumbu pipa seperti terlihat pada Gambar 4. Nilai tegangan tersebut dapat dirumuskan sebagai berikut.

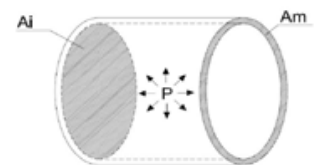

Gambar 4. Tegangan Tekan

(Sumber: Jamaludin, Achmad, jurnal 2016, Analisis Tegangan Sistem Perpipaan Pada Sisi Tekan Pompa P003E Menggunakan Caesar II dan Perhitungan Manual, hal 10.)

Dengan demikian tegangan longitudinal secara keseluruhan adalah jumlah dari gaya aksial + tekanan dalam pipa + bending momen pipa, sehingga dapat dituliskan seperti persamaan berikut ini:

$$
S_{L}=\frac{F_{a x}}{A_{m}}+\frac{P . d_{o}}{4 t}+\frac{M_{b}}{Z}
$$

\subsubsection{Tegangan Tangensial}

Tegangan ini disebabkan oleh tekanan dalam pipa dimana tekanan ini bersumber dari fluida dan nilainya selalu positif jika tegangan cenderung membelah pipa menjadi dua. Rumus untuk tegangan tangensial dapat didekati dengan memakai persamaan berikut.

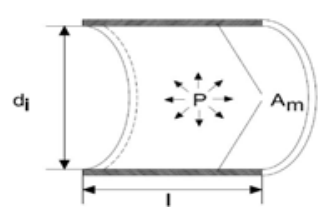

Gambar 5. Tegangan Tangensial

(Sumber: Jamaludin, Achmad, jurnal 2016, Analisis Tegangan Sistem Perpipaan Pada Sisi Tekan Pompa P- 
003E Menggunakan Caesar II dan Perhitungan Manual, hal 9)

$$
S_{H}=\frac{P . d_{o}}{2 . t}
$$

\subsubsection{Tegangan Radial}

Nilai tegangan radial terbesar (maksimum) terjadi pada dinding dalam pipa, sedangkan nilai tegangan redial terkecil (minimum) terjadi pada dinding luar pipa. $^{2}$

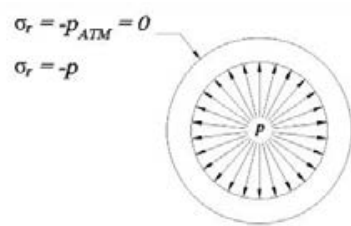

Gambar 6. Tegangan Radial

(Sumber: Jamaludin, Achmad, jurnal 2016, Analisis Tegangan Sistem Perpipaan Pada Sisi Tekan Pompa P003E Menggunakan Caesar II dan Perhitungan Manual, hal 10)

$$
S_{R}=\frac{P \cdot r_{i}^{2}}{r_{o}^{2}-r_{i}^{2}}\left(1-\frac{r_{o}^{2}}{r^{2}}\right)
$$

\subsubsection{Tegangan Geser}

Tegangan geser pada sistem perpipaan antara lain akibat gaya dari tumpuan pipa (pipe support) dikombinasikan dengan gaya tekuk.

\section{Akibat Gaya Geser V}

Tegangan ini maksimum di sumbu netral (sumbu simetri pipa) dan tidak bernilai pada titik di mana tegangan lendut maksimum (pada permukaan luar dinding pipa). Akibat hal ini dan besar tegangan ini biasanya sangat kecil, maka tegangan ini diabaikan seperti terlihat pada Gambar 7 dibawah ini.

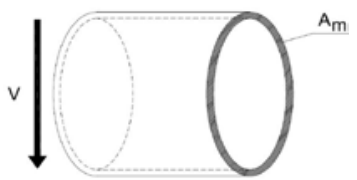

Gambar 7. Tegangan Geser

(Sumber: Jamaludin, Achmad, Jurnal 2016, Analisis Tegangan Sistem Perpipaan Pada Sisi Tekan Pompa P003E Menggunakan Caesar II dan Perhitungan Manual, hal 11)

$$
\tau_{\max }=\frac{V \cdot Q}{A_{m}}
$$

\section{Akibat Momen Puntir}

Tegangan ini maksimum pada titik yang sama dimana tegangan lendut maksimum seperti terlihat pada Gambar 8 dibawah ini.

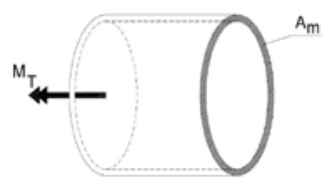

Gambar 8. Tegangan Puntir

(Sumber: Jamaludin, Achmad, Jurnal 2016, Analisis Tegangan Sistem Perpipaan Pada Sisi Tekan Pompa P003E Menggunakan Caesar II dan Perhitungan Manual, hal 12)

$$
S_{T}=\frac{M_{T}}{2 . Z}
$$

\subsection{Kode dan Standar Perpipaan}

Kegiatan perekayasaan untuk memperoleh prilaku sistem pipa ini dikenal sebagai analisis tegangan pipa atau dahulu disebut juga analisis flexibilitas (Raswari, 2007). Kode dan Standar perpipaan adalah satu set persyaratan minmum yang harus digunakan pada setiap sistem perpipaan yang dibangun agar aman. Standar mencantumkan spesifikasi material yang diizinkan, rancang fabrikasi yang dapat diterima, serta persyaratan dan prosedur inspeksi (Dahlan, 2016)

Pada saat ini ada beberapa buah kode standar dari komite B31 ini yang sering dipakai sebagai acuan di Indonesia sesuai kebutuhan bidang industri, yaitu:

- ASME/ANSI B31.1 untuk sistem perpipaan di industri pembangkit listrik;

- ASME/ANSI B31.3 untuk sistem perpipaan di industri proses dan petrokimia;

- ASME/ANSI B31.4 untuk pipa transport minyak dan zat cair lainnya;

- ASME/ANSI B31.5 untuk sistem perpipaan pendingin;

- ASME/ANSI B31.8 untuk pipa transport gas.

2.3.1. Analisis ASME B31.1

ASME B31.1 adalah jenis code yang digunakan dalam analisa tegangan pada system power piping (perpipaan daerah proses atau sekitar proses contohnya: turbin dan boiler), pada tugas akhir ini akan dibahas tentang analisis tegangan pipa pada sistem instalasi perpipaan geothermal di proyek $\mathrm{x}$, dan sistem perpipaan geothermal itu sendiri digolongkan pada code ini.

\section{Beban Sustain}

Beban Sustained adalah beban akibat berat pipa, berat fluida, tekanan dalam pipa, tekanan luar, pengaruh angin dan gempa serta beban dari salju yang menimpa pipa. Sustained load merupakan tegangan primer yang menyebabkan kegagalan katastrofis. Jumlah dari seluruh tegangan longitudinal $\left(\mathrm{S}_{\mathrm{L}}\right)$ akibat tekanan, berat dan akibat beban sustain yang lain tidak boleh melebihi $\left(\mathrm{S}_{\mathrm{H}}\right)$ (Manurung, 2013). Secara matematis persamaan dari sustained load dapat digambarkan seperti berikut: 


$$
S_{L}=\frac{P d_{o}}{4 t}+\frac{(0.75 i) M_{A}}{Z} \leq 1.0 S_{h}
$$

\section{Beban Ekpansi}

Beban Ekspansi adalah adalah stress yang terjadi akibat adanya perubahan temperatur, jika temperatur naik akan mengakibatkan pemuaian sedangkan jika suhu menurun maka akan terjadi pengkerutan. Pemuaian dan pengkerutan akan mengakibatkan kegagalan dan kebocoran pada sambungan, misalnya sambungan pada pompa, vessel, tank dan lain-lain

Stress yang diakibatkan oleh adanya ekspansi termal dan atau displacement (pergeseran) $S_{E}$ akan dihitung sebagai berikut:

$$
S_{E}=\frac{i M_{C}}{Z} \leq S_{A}+f\left(S_{h}-S_{L}\right)
$$

Adapun batasan tegangan maksimum yang diizinkan material karena beban ekspansi adalah sebagai berikut:

$$
S_{A}=f\left(1,25 S_{\mathrm{c}}+1,25 S_{h}-S_{L}\right)
$$

Untuk menganalisis momen tekuk yang terjadi akibat perubahan temperatur maka terdapat teknik tersendiri yang dijadikan penulis sebagai acuan yaitu dengan menggunakan metode Grinnell. Tegangan ekspansi yang terjadi akan dibandingkan dengan tegangan izin bahan, jika tegangan ekspansi yang terjadi lebih kecil dari tegangan izin bahan maka kontruksi sistem pipa tersebut aman.

Adapun langkah-langkah yang dilakukan dalam melakukan menghitung momen tekuk pada sistem perpipaan dengan teknik single plane antara lain:

\section{a. Menentukan titik berat dari setiap komponen pipa dalam satu rangkaian}

- Untuk pipa lurus, seperti terlihat pada Gambar 9 dibawah ini.

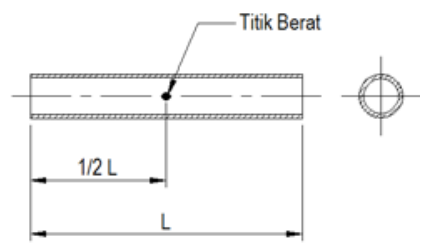

Gambar 9. Posisi titik berat untuk pipa lurus (Sumber: Veranika, R.M, Jurnal Desiminasi Teknologi, Vol. 3, No.1, hal. 92-100)

\section{b. Menenentuan titik pusat (centeroid) untuk satu bidang acuan}

Untuk pipa lurus, seperti terlihat pada Gambar 10 dibawah ini.

$$
=L \cdot X^{\prime}
$$

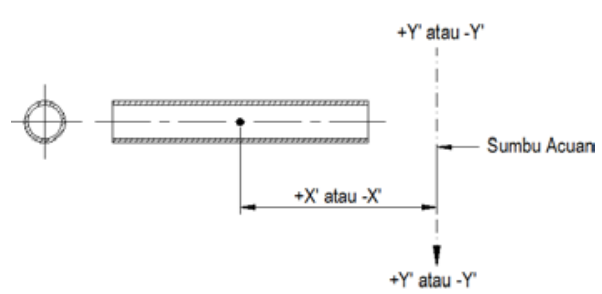

Gambar 10. Posisi titik pusat pada pipa lurus (Sumber: Veranika, R.M, Jurnal Desiminasi Teknologi, Vol. 3, No.1, hal. 92-100)

- Untuk pipa lurus yang tegak lurus dengan sumbu acuan, seperti terlihat pada Gambar 11 dibawah ini.

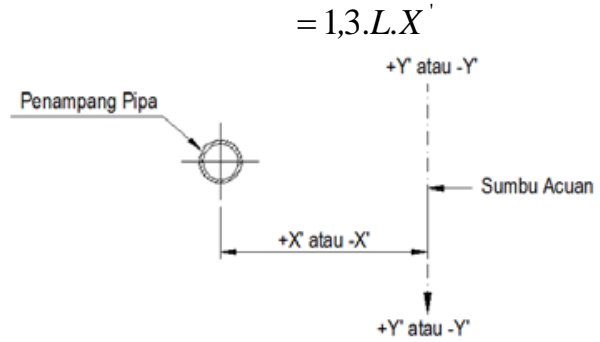

Gambar 11. Posisi titik pusat pada pipa yang tegak lurus sumbu acuan

(Sumber: Veranika, R.M, Jurnal Desiminasi Teknologi, Vol. 3, No.1, hal. 92-100)

\section{c. Menentukan momen inersia suatu bidang (jarak titik berat terhadap garis sumbu)}

- Untuk pipa lurus

$$
I x y=L . X . Y
$$

- Untuk pipa lurus yang tegak lurus dengan sumbu acuan

$$
I x y=1,3 \cdot L \cdot X \cdot Y
$$

\section{d. Menentukan momen inersia pada satu sumbu}

- Untuk pipa lurus horizontal, seperti terlihat pada Gambar 12 dibawah ini.

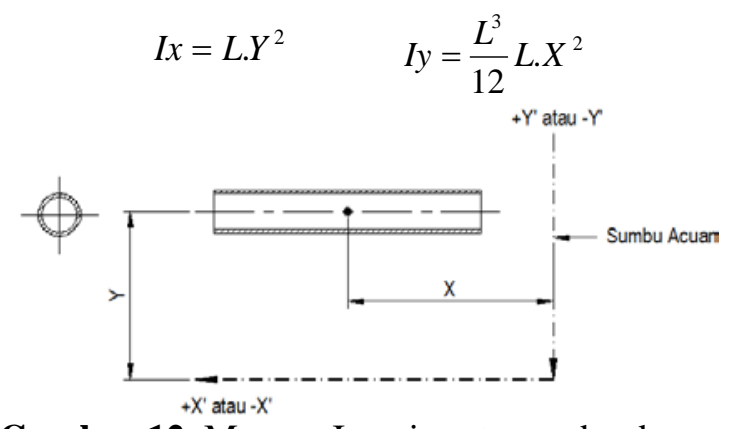

Gambar 12. Momen Inersia satu sumbu dengan orientasi pipa lurus Horizontal

(Sumber: Veranika, R.M, Jurnal Desiminasi Teknologi, Vol. 3, No.1, hal. 92-100)

- Untuk pipa lurus vertical, seperti terlihat pada Gambar 13 dibawah ini.

$$
I x=\frac{L^{3}}{12} L \cdot Y^{2} \quad I y=L \cdot X^{2}
$$




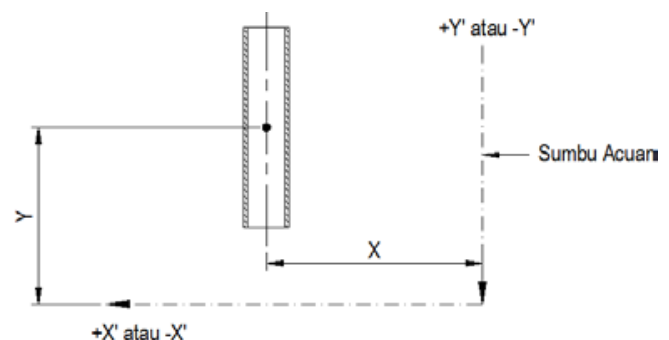

Gambar 13. Momen Inersia satu sumbu dengan orientasi pipa lurus Vertikal

(Sumber: Veranika, R.M, Jurnal Desiminasi Teknologi, Vol. 3, No.1, hal. 92-100)

- Untuk pipa lurus yang tegak lurus dengan bidang, seperti terlihat pada Gambar 14 dibawah ini.

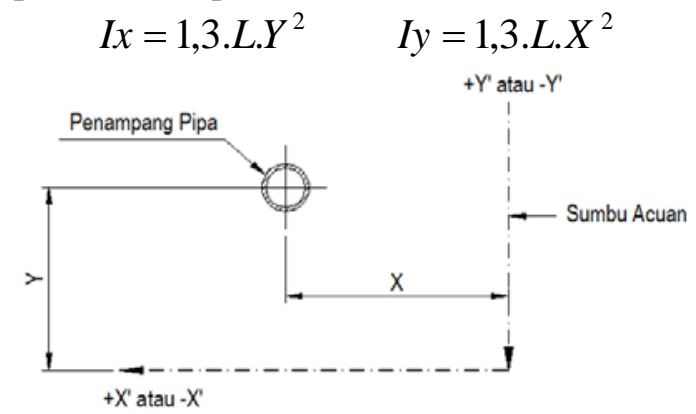

Gambar 14. Momen Inersia satu sumbu dengan orientasi pipa lurus yang tegak lurus dengan bidang acuan

(Sumber: Veranika, R.M, Jurnal Desiminasi Teknologi, Vol. 3, No.1, hal. 92-100)

\section{e. Menentukan gaya yang bekerja pada sumbu $\mathbf{X}, \mathbf{Y}, \mathbf{Z}$}

Setelah momen inersia bidang dan momen inersia pada satu sumbu telah diketahui, maka langkah selanjutnya adalah menentukan gaya-gaya yang bekerja pada sumbu $\mathrm{x}, \mathrm{y}$, dan $\mathrm{z}$ dengan cara sebagai berikut:

$$
\begin{aligned}
& F x . I x-F y . I x y-F z . I x z=\Delta x . E . I \\
& -F x . I x y+F y . I y-F z . I y z=\Delta y . E . I \\
& -F x . I x z-F y . I y z+F z . I z=\Delta z . E . I
\end{aligned}
$$

\subsection{Pengetahuan Perpipaan}

Pengetahuan perpipaan merupakan suatu sarana dan dasar dalam melakukan perhitungan, penganalisaan suatu instalasi perpipaan agai mencapai titik menuju kesempurnaan. Adapun halhal yang perlu diketahui dalam suatu sistem perpipaan antara lain:

\section{Jenis Pipa}

secara umum jenis pipa dapat dikelompokkan menjadi dua bagian yaitu:

a. Jenis pipa tanpa sambungan (pembuatan pipa tanpa sambungan pengelasan).

b. Jenis pipa dengan sambungan (pembuatan pipa dengan pengelasan)

\section{Bahan-bahan Pipa Secara Umum}

Bahan-banan pipa yang dimaksudkan disini adalah struktur bahan baru pipa yang dapat dibagi secara umum sebagai berikut:

- Carbon steel, Carbon moly, Galvanize, Ferro nikel

- Stainless steel, PVC (paralon) dan Chrome moly

3. Komponen Perpipaan

Komponen perpipaan harus dibuat berdasarkan spesifikasi, standara yang terdaftar dalam simbol dan kode yang telah dibuat atau dipilih sebelumnya. Komponen perpipaan yang dimaksud disini meliputi:

- $\quad$ Pipe (pipa), Flange (flens), Fitting (sambungan), Valve (katup), Bolting (baut) dan Gasket

\section{Macam Sambungan Perpipaan}

Sambungan perpipaan dapat dikelompokkan sebagai berikut:

a. Sambungan dengan menggunakan pengelasan.

b. Sambungan dengan menggunakan ulir.

\section{Tipe Sambungan Cabang}

Tipe sambungan cabang (branch connection) dapat dikelompokkan sebagai berikut:

a. Sambungan langsung (stub in).

b. Sambungan dengan menggunakan fitting (alat penyambung).

c. Sambungan dengan menggunakan flange (flens).

\section{Diameter, Ketebalan, Schedule}

Diameter nominal adalah diameter pipa yang dipilih untuk pemasangan ataupun perdagangan (commodity). Ketebalan dan schedule sangatlah berhubungan, hal ini karena ketebalan pipa tergantung dari pipa itu sendiri.

Schedule pipa ini dapat dikelompokkan sebagai berikut:

- Schedule: 5, 10, 20, 30, 40, 60, 80, 100, 120, 160.

- Schedule standard.

- Schedule extra strong (XS).

- Schedule double extra strong (XXS).

- Schedule special.

Perbedaan-perbedaan schedule ini dibuat guna:

a. Menahan internal pressure dari aliran.

b. Kekuatan dari material itu sendiri (strength of materials).

c. Mengatasi karat.

d. Mengatasi kegetasan pipa.

Berdasarkan kode ASME B31.3 mensyaratkan tebal minimum pipa didasarkan pada tekanan internal mencakup batas kelonggaran (allowance) untuk kekuatan mekanis tidak boleh kurang dari ketebalan yang dihitung dengan menggunakan persamaan dibawah ini. 


$$
t_{m}=\frac{P . d_{o}}{2\left(S E_{q}+P Y\right)}+A
$$

\subsection{Jarak Maksimum antar Tumpuan Pipa}

Jarak Allowable span sendiri sangat penting dalam upaya menjaga agar sistem perpipaan tidak mengalami tegangan yang berlebih (overstress) akibat berat pipa dan fluida didalamnya. Dengan perhitungan sederhana berdasarkan persyaratan tegangan menggunakan rumus dibawah ini.

$$
L=\sqrt{\frac{0,4 \cdot Z \cdot S_{h}}{W}}
$$

\section{METODE DAN PENGOLAHAN DATA}

\subsection{Metode Penelitian}

Metode yang digunakan untuk menyelesaikan permasalahan dalam analisis tegangan pada sistem perpipaan yaitu dengan pengamatan langsung dilapangan dan mengumpulkan data-data pendukung berdasarkan keadaan yang sebenarnya terjadi pada saat itu, yang selanjutnya oleh penulis dipakai sebagai dasar untuk dianalisis.

Diagram alir dalam proses pelaksanaan penelitian yang akan dilakukan seperti terlihat pada Gambar 15 dibawah ini.
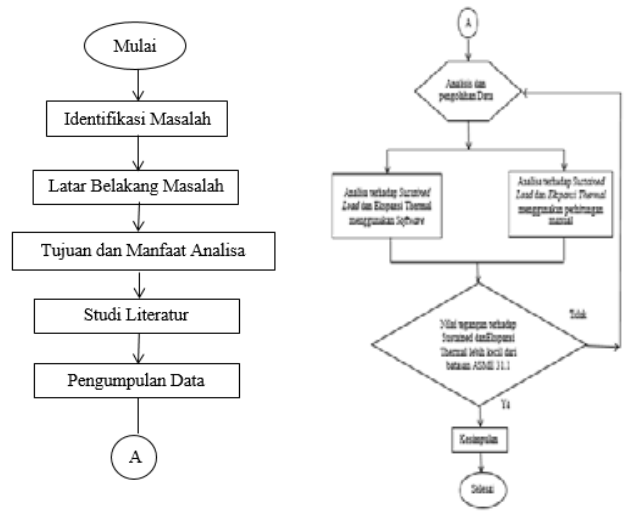

Gambar 15. Diagram Alir Metode Penelitian Safasd

\subsection{Prosedur Pengambilan Data}

Penulis mengadakan penelitian langsung pada perusahaan untuk memperoleh data atau bahan yang seobjektif mungkin. Adapun cara yang ditempuh adalah sebagai berikut.

a. Pengamatan

b. Wawancara Berstruktur

Cara ini dilakukan dengan mengadakan wawancara langsung kepada pihak yang berwenang dalam perusahaan dengan melakukan tanya-jawab, yang selanjutnya hasilnya dianalisa sesuai dengan judul tugas akhir. Pertanyaan yang diajukan antara lain data tentang Piping \& Instrument Diagram, Plot Plan, Spesifikasi, dan data material.

\subsubsection{Proses Sistem Perpipaan}

Dalam perancangan suatu proyek memerlukan data-data pendukung untuk proses engineering yang memiliki keterkaitan satu dokumen dengan dokumen yang lainnya yang merupakan ringkasan yang telah disederhanakan dari berbagai spesifikasi dan ketentuan suatu proyek. Dokumen-dokumen tersebut adalah Proses Flow Diagram (PFD), Piping and Instrumentation Diagram (P\&ID), Piping Plan, Isometric Drawing, dan Pipe Support seperti terlihat pada Gambar 16, Gambar 17, Gambar 18, Gambar 19, Gambar 20 dibawah ini.

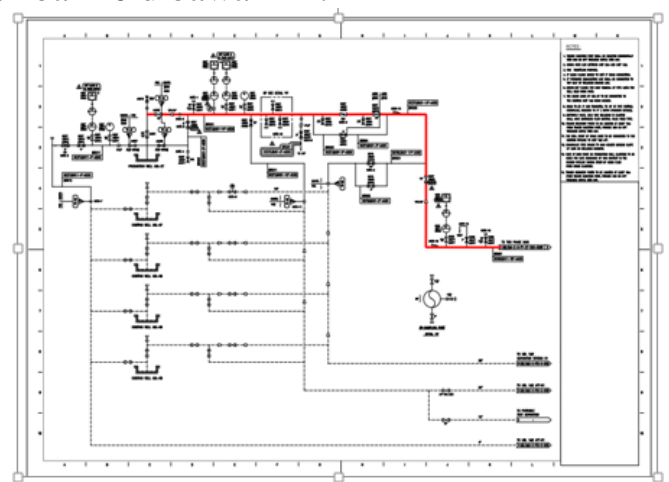

Gambar 16. Piping and Instrument Diagram (Sumber: Documentum Proyek $X$ )

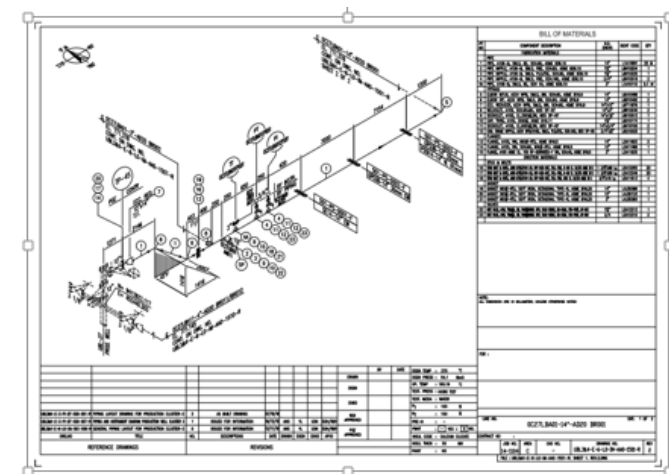

Gambar 17. Isometric Drawing Line Number 0C27LBA01-14"-AD20 BR001 Sheet 1 of 2 (Sumber: Documentum Proyek $X$ )

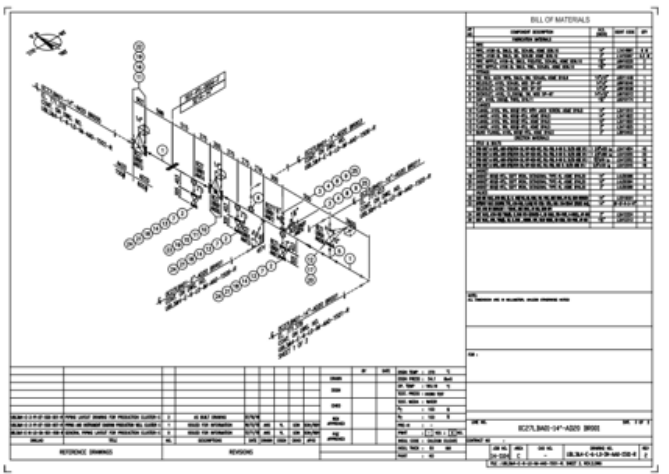

Gambar 18. Isometric Drawing Line Number 0C27LBA01-14"-AD20 BR001 Sheet 2 of 2 (Sumber: Documentum Proyek $X$ ) 


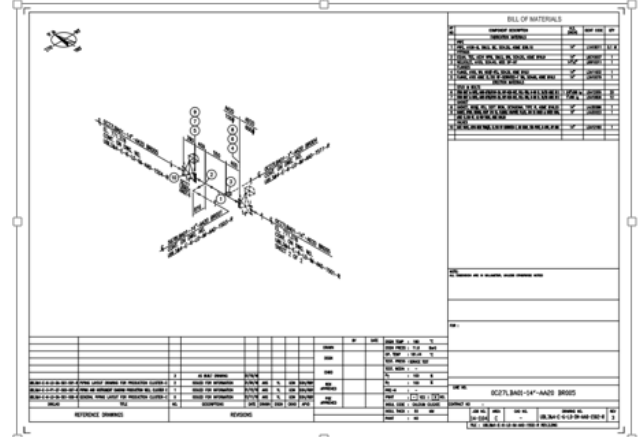

Gambar 19. Isometric Drawing Line Number 0C27LBA01-14"-AA20 BR005 (Sumber: Documentum Proyek $X$ )

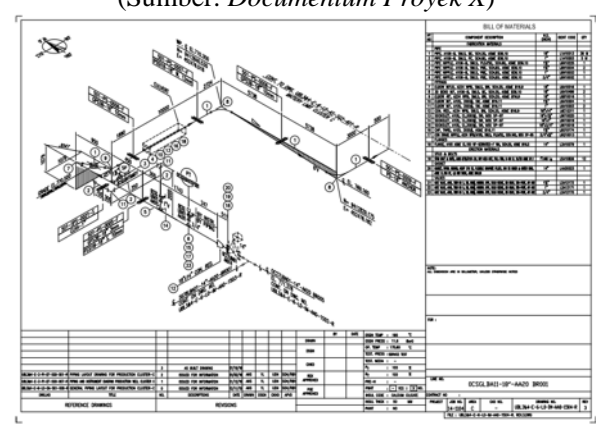

Gambar 20. Isometric Drawing Line Number OCSGLBA11-18-AA20 BR001 (Sumber: Documentum Proyek $X$ )

\subsection{Alat yang Digunakan}

1 Meteran Laser: Berfungsi untuk mengukur jarak dengan jangkauan yang jauh dan ketinggian.

2 Meteran Manual: Berfungsi untuk mengukur dengan area yang bisa di jangkau oleh tangan atau area jarak dekat.

3 Kamera Digital: Berfungsi untuk mengambil gambar pada area yang akan di ganti.

4 Komputer atau Laptop: Berfungsi untuk membuat gambar dengan software autoCAD dan PDMS.

\subsection{Spesifikasi Data}

Pengumpulan data yang dilakukan di Proyek X, diperoleh data-data sistem perpipaan pada area cluster, Adapun parameter-parameter yang menjadi dasar perhitungan manual dan data masukan (input) kedalam program CAESAR II yang akan diproses adalah berikut:

1) Pipe data Class AD20 (600\#)

- Design code: ASME B31.1

- Material: SCH 60, A106 Gr. B

- wall thickness: $15 \mathrm{~mm}$

- Inside Diameter $\left(d_{i}\right): 325 \mathrm{~mm}$

- Outside Diameter $\left(d_{o}\right): 356 \mathrm{~mm}$

- Operating pressure (P2): 11,67 bar $=11,9001$ $\mathrm{kg} / \mathrm{cm}^{2}$

- Operating temperature (T2): $374,342{ }^{0} \mathrm{~F}=190,19$ ${ }^{0} \mathrm{C}$

- Design pressure (P1): 54,1 bar $=55,1666 \mathrm{~kg} / \mathrm{cm}^{2}$

- Design temperature (T1): $518{ }^{\circ} \mathrm{F}=270{ }^{\circ} \mathrm{C}$
- Hydrotest pressure: 81,1500 bar

- Corrosion Allowance (A): 3 mm

- Fluid: Two Phase

- Fluid density: $300 \mathrm{~kg} / \mathrm{m}^{3}$

- Pipe density: 7833,43994 kg/m³

- Modulus of Elasticity (E): 2,0682 x 106 kg/cm2 = $20682 \mathrm{~kg} / \mathrm{mm} 2$

- Mill Tolerance: $12,5 \%$ (database program)

- Weld Joint Factor (Ej): 1 (untuk pipa tanpa sambungan)

- Coefficient Y: 0,4 (temperatur dibawah $900^{\circ} \mathrm{F}$ )

- Max. yield strength (Sy): 2460,500 kg/ $\mathrm{cm}^{2}$

- Max. Allowable stress (S): 1202,130 kg/ $\mathrm{cm}^{2}$

- Max. tensile stress (Sh): 1202,130 kg/cm²

2) Pipe data Class AA20 (150\#)

- Design code: ASME B31.1

- Material: SCH 60, A106 Gr. B

- wall thickness: $8 \mathrm{~mm}$

- Inside Diameter $\left(d_{i}\right): 340 \mathrm{~mm}$

- Outside Diameter $\left(d_{o}\right): 356 \mathrm{~mm}$

- Operating pressure (P2): 9,44 bar = 9,62612 $\mathrm{kg} / \mathrm{cm}^{2}$

- Operating temperature (T2): $358,628{ }^{0} \mathrm{~F}=181,46$ ${ }^{0} \mathrm{C}$

- Design pressure (P1): 11,6 bar $=11,8287 \mathrm{~kg} / \mathrm{cm}^{2}$

- Design temperature (T1): $374^{0} \mathrm{~F}=190{ }^{\circ} \mathrm{C}$

- Hydrotest pressure: 17,4 bar

- Corrosion Allowance (A): 3 mm

- Fluid: Two Phase

- Fluid density: $300 \mathrm{~kg} / \mathrm{m}^{3}$

- Pipe density: 7833,43994 kg/m³

- Modulus of Elasticity (E): 2,0682 x $106 \mathrm{~kg} / \mathrm{cm} 2$ = $20682 \mathrm{~kg} / \mathrm{mm} 2$

- Mill Tolerance: $12,5 \%$ (database program)

- Weld Joint Factor (Ej): 1 (untuk pipa tanpa sambungan)

- Coefficient Y: 0,4 (temperatur dibawah $900^{\circ} \mathrm{F}$ )

- Max. yield strength (Sy): 2460,500 kg/ $\mathrm{cm}^{2}$

- Max. Allowable stress (S): 1202,130 kg/ $\mathrm{cm}^{2}$

- Max. tensile stress (Sh): 1202,130 kg/ $\mathrm{cm}^{2}$

3) Pipe data Class AA20 (150\#)

- Design code: ASME B31.1

- Material: SCH 60, A106 Gr. B

- wall thickness: $8 \mathrm{~mm}$

- Inside Diameter $\left(d_{i}\right): 441 \mathrm{~mm}$

- Outside Diameter $\left(d_{o}\right): 457 \mathrm{~mm}$

- Operating pressure (P2): 8,12 bar $=8,2801 \mathrm{~kg} / \mathrm{cm}^{2}$

- Operating temperature (T2): $348,08{ }^{0} \mathrm{~F}=175,60{ }^{\circ} \mathrm{C}$

- Design pressure (P1): 11,6 bar $=11,8287 \mathrm{~kg} / \mathrm{cm}^{2}$

- Design temperature (T1): $374^{0} \mathrm{~F}=190{ }^{\circ} \mathrm{C}$

- Hydrotest pressure: 17,4 bar

- Corrosion Allowance (A): $3 \mathrm{~mm}$

- Fluid: Two Phase

- Fluid density: $300 \mathrm{~kg} / \mathrm{m}^{3}$

- Pipe density: 7833,43994 kg/m³ 
- Modulus of Elasticity (E): 2,0682 x 106 kg/cm2 = $20682 \mathrm{~kg} / \mathrm{mm}^{2}$

- Mill Tolerance: $12,5 \%$ (database program)

- Weld Joint Factor (Ej): 1 (untuk pipa tanpa sambungan)

- Coefficient Y: 0,4 (temperatur dibawah $900^{\circ} \mathrm{F}$ )

- Max. yield strength (Sy): 2460,500 kg/ $\mathrm{cm}^{2}$

- Max. Allowable stress (S): 1202,130 kg/cm²

- Max. tensile stress (Sh): 1202,130 kg/cm²

Tabel 1. Ringkasan berat komponen perpipaan

\begin{tabular}{|c|l|c|c|}
\hline No & \multicolumn{1}{|c|}{ MATERIAL DESCRIPTION } & \multicolumn{2}{c|}{ WEIGHT } \\
\hline 1 & PIPE, 14", A106-B, SMLS, BE, SCH 60 & 127 & $\mathrm{Kg} / \mathrm{m}$ \\
\hline 2 & ELBOW 45", 14", A234 WPB, SMLS, BW, SCH 60 & 52,62 & $\mathrm{~kg}$ \\
\hline 3 & ELBOW 90, 14", A234 WPB, SMLS, BW, SCH 60 & 105,41 & $\mathrm{~kg}$ \\
\hline 4 & FLANGE, 14", A105, WN, 600\#-RTJ (include bolt \& nuts) & 192,76 & $\mathrm{~kg}$ \\
\hline 5 & FLANGE, 12", A105, WN, 900\#-RTJ (include bolt \& nuts) & 217,01 & $\mathrm{~kg}$ \\
\hline 6 & ECC. REDUCER, 14"x12", A234 WPB, SMLS, BW, SCH 60 & 45,53 & $\mathrm{~kg}$ \\
\hline 7 & GATE VALVE, 14", 600\# RTJ & 1192,77 & $\mathrm{~kg}$ \\
\hline 8 & BUTTERFLY VALVE, 14", 600\# RTJ & 229,54 & $\mathrm{~kg}$ \\
\hline 9 & PIPE, 14", A106-B, SMLS, BE, SCH 20 & 69 & $\mathrm{Kg} / \mathrm{m}$ \\
\hline 10 & FLANGE, 14", A105, WN, 150\# RF (include bolt \& nuts) & 63,89 & $\mathrm{~kg}$ \\
\hline 11 & EQUAL TEE, 14", A234 WPB, SMLS, BW, SCH 20 & 63,34 & $\mathrm{~kg}$ \\
\hline 12 & GATE VALVE, 14", 150\# RF & 398,24 & $\mathrm{~kg}$ \\
\hline 13 & PIPE, 18", A106-B, SMLS, BE, SCH 20 & 89 & $\mathrm{Kg} / \mathrm{m}$ \\
\hline 14 & ELBOW 90', A234 WPB, SMLS, BW, SCH 20 & 95,33 & $\mathrm{~kg}$ \\
\hline 15 & ELBOW 45", A234 WPB, SMLS, BW, SCH 20 & 47,66 & $\mathrm{~kg}$ \\
\hline 16 & CON.REDUCER, 18"x14" A234 WPB, SMLS, BW, SCH 20 & 34,16 & $\mathrm{~kg}$ \\
\hline
\end{tabular}

\subsection{Perhitungan dan simulasi}

\subsubsection{Perhitungan Ketebalan Minimum Dinding Pipa}

Setiap pipa memiliki ketebalan yang berbeda-beda sesuai dengan keadaan sistem perpipaan itu.

$$
\begin{aligned}
t_{m} & =\frac{P D_{0}}{2(S E+P Y)}+A \\
& =1,10 \mathrm{~cm}=11 \mathrm{~mm}
\end{aligned}
$$

Untuk pipa 14 inch dengan SCH 60 maka ketebalan minimum dinding pipanya adalah $11 \mathrm{~mm}$ sedangkan untuk pipa 14 inch dengan SCH 20 maka ketebalan minimum dinding pipanya adalah $4,71 \mathrm{~mm}$

$$
\begin{aligned}
t_{m} & =\frac{P D_{0}}{2(S E+P Y)}+A \\
& =0,52 \mathrm{~cm}=5,2 \mathrm{~mm}
\end{aligned}
$$

Untuk pipa 18 inch dengan SCH 20 maka ketebalan minimum dinding pipanya adalah $5,2 \mathrm{~mm}$

\subsubsection{Perhitungan Jarak Maksimum Penyangga Pipa}

Ketepatan pemilihan dan perhitungan jarak penyangga menjadi factor penentu dalam keberhasilan analisis fleksibilitas.

$$
\begin{aligned}
W=W_{p}+W_{c} & \Rightarrow W_{p}=\pi / 4\left(d_{o}{ }^{2}-d_{i}{ }^{2}\right) \times \text { density of pipe } \\
& \Rightarrow W_{c}=\pi / 4\left(d_{i}{ }^{2}\right) \times \text { density of fluida }
\end{aligned}
$$

Penyelesaian:

- Perhitungan berat pipa per satuan panjang

$$
\begin{gathered}
W_{p}=\pi / 4\left(d_{o}^{2}-d_{i}^{2}\right) \times \text { density of pipe } \\
=129,81 \mathrm{~kg} / \mathrm{m} \\
W_{c}=\pi / 4\left(d_{i}^{2}\right) \times \text { density of fluida } \\
=24,87 \mathrm{~kg} / \mathrm{m}
\end{gathered}
$$

Maka nilai W untuk pipa 14" SCH 60 adalah $\mathrm{W}=\mathrm{Wp}+\mathrm{Wc}=129,81+24,87=154,68 \mathrm{~kg} / \mathrm{m}$, sedangkan untuk nilai W untuk pipa 14" SCH 20 adalah $\mathrm{W}=\mathrm{Wp}+\mathrm{Wc}=68,47+27,22=95,69 \mathrm{~kg} / \mathrm{m}$

$W_{p}=\pi / 4\left(d_{o}{ }^{2}-d_{i}^{2}\right) \times$ density of pipe

$=86,14 \mathrm{~kg} / \mathrm{m}$

$W_{c}=\pi / 4\left(d_{i}^{2}\right) \times$ density of fluida

$=45,80 \mathrm{~kg} / \mathrm{m}$

Maka nilai W untuk pipa 18” SCH 20 adalah $\mathrm{W}=\mathrm{Wp}+\mathrm{Wc}=86,14+45,80=131,94 \mathrm{~kg} / \mathrm{m}$

- Perhitungan modulus penampang pipa (Z) Untuk pipa 14" SCH 60 adalah

$$
\begin{aligned}
Z & =\frac{\pi\left(d_{o}{ }^{4}-d_{i}{ }^{4}\right)}{32 d_{o}} \\
& =1352078 \mathrm{~mm}^{3}
\end{aligned}
$$

\section{Perhitungan Tegangan Pipa Akibat Beban Sustain dengan Perhitungan Manual}

Nilai tegangan longitudinal pada node 180 adalah.

$$
\begin{aligned}
S_{L} & =\frac{P d_{o}}{4 t}+\frac{(0,75 i) M_{A}}{Z} \leq S_{h} \\
& =327,3 \mathrm{~kg} / \mathrm{cm}^{2}
\end{aligned}
$$

\section{Perhitungan Tegangan Aksial $\left(S_{a x}\right)$}

Untuk menghitung tegangan akibat gaya yang searah dengan sumbu pipa.

$$
\begin{aligned}
A_{i}= & \frac{\pi}{4} d_{i}^{2} \\
& =82915,625 \mathrm{~mm}^{2}=829,15625 \mathrm{~cm}^{2} \\
F_{a x} & =P \cdot A_{i} \\
& =55,1666 \mathrm{~kg} / \mathrm{cm}^{2} \times 829,15625 \mathrm{~cm}^{2} \\
& =45742 \mathrm{~kg} \\
A_{m} & =\frac{\pi}{4}\left(d_{o}{ }^{2}-d_{i}{ }^{2}\right) \\
& =16572,135 \mathrm{~mm}^{2}=165,721 \mathrm{~cm}^{2} \\
S_{a x} & =\frac{F_{a x}}{A_{m}}=\frac{45741,6 \mathrm{~kg}}{165,721 \mathrm{~cm}^{2}}=276,015 \mathrm{~kg} / \mathrm{cm}^{2}
\end{aligned}
$$

2. Perhitungan Tegangan Tekan (Sp)

Untuk menghitung tegangan akibat tekanan dalam pipa.

$$
\begin{gathered}
S_{p}=\frac{P . d_{o}}{4 t}=327 \mathrm{~kg} / \mathrm{cm}^{2} \\
\text { 3. } \begin{array}{l}
\text { Perhitungan } \\
\text { Tangensial }\left(S_{H}\right)
\end{array} \\
S_{H}=\frac{P . d_{o}}{2 t}=655 \mathrm{~kg} / \mathrm{cm}^{2}
\end{gathered}
$$

Tegangan

4. Perhitungan Tegangan Radial $\left(S_{R}\right)$ 


$$
S_{R}=\frac{P . r_{i}^{2}}{r_{o}^{2}-r_{i}^{2}}\left(1-\frac{r_{o}^{2}}{r^{2}}\right)=-52,44 \mathrm{~kg} / \mathrm{cm}^{2}
$$

3. Perhitungan Tegangan Pipa Akibat Beban Ekspansi dengan Perhitungan Manual

Untuk mendapatkan tegangan tekuk dan tegangan torsi pada sistem peripaan penulis menggunakan metode Grinnell dengan membagi gambar sistem perpipaan dari bentuk 3 dimensi menjadi gambar proyeksi 2 dimensi dengan sumbu $\mathrm{X}-\mathrm{Y}, \mathrm{X}-\mathrm{Z}, \mathrm{Y}-\mathrm{Z}$. Pembagian tersebut dinamakan single plane system.

1. Perhitungan Titik Pusat (centeroid) pada Bidang X-Y

Tabel 2. Penentuan nilai centeroid bidang X-Y

\begin{tabular}{|c|r|r|r|r|r|}
\hline Node & \multicolumn{1}{c|}{$\mathrm{L}(\mathrm{mm})$} & \multicolumn{1}{c|}{$\mathrm{X}(\mathrm{mm})$} & \multicolumn{1}{c|}{ L.X $\left(\mathrm{mm}^{2}\right)$} & \multicolumn{1}{c|}{$\mathrm{Y}(\mathrm{mm})$} & \multicolumn{1}{c|}{$\mathrm{L} . \mathrm{Y}^{2}\left(\mathrm{~mm}^{2}\right)$} \\
\hline $10007-150$ & 3417.00 & 17085.00 & 58379445.00 & 0.00 & 0.00 \\
\hline $150-160$ & 2603.90 & 4125.00 & 10741087.50 & 0.00 & 0.00 \\
\hline $160-210$ & 17968.00 & 13817.00 & 248263856.00 & 0.00 & 0.00 \\
\hline $210-220$ & 2600.00 & 0.00 & 0.00 & 1300.00 & 3380000.00 \\
\hline $220-280$ & 3514.00 & 0.00 & 0.00 & 4356.00 & 15306984.00 \\
\hline $310-350$ & 1359.00 & 0.00 & 0.00 & 7016.00 & 9534744.00 \\
\hline $380-400$ & 4201.00 & 0.00 & 0.00 & 10865.50 & 45645965.50 \\
\hline $400-410$ & 3953.30 & 23340.50 & 92271998.65 & 0.00 & 0.00 \\
\hline $410-430$ & 14614.00 & 37141.00 & 542778574.00 & 0.00 & 0.00 \\
\hline $430-440$ & 11476.00 & 0.00 & 0.00 & 18704.00 & 214647104.00 \\
\hline $440-450$ & 3500.00 & 40254.00 & 140889000.00 & 0.00 & 0.00 \\
\hline Total & 69206.20 & & 1093323961.15 & & 288514797.50 \\
\hline
\end{tabular}

Maka posisi titik pusat dari sumbu X-Y adalah:

$\underline{X}=\frac{\sum L X^{i}}{\sum L}=\frac{1093323961,15 \mathrm{~mm}^{2}}{69206,20 \mathrm{~mm}}=15798,06 \mathrm{~mm}\left(\right.$ ke kanan dari sumbu $\left.\mathrm{Y}^{\mathrm{i}}\right)$

$\underline{Y}=\frac{\sum L Y^{i}}{\sum L}=\frac{375069236,75 \mathrm{~mm}^{2}}{69206,20 \mathrm{~mm}}=4168,92 \mathrm{~mm}\left(\right.$ ke atas dari sumbu $\left.\mathrm{X}^{\mathrm{i}}\right)$

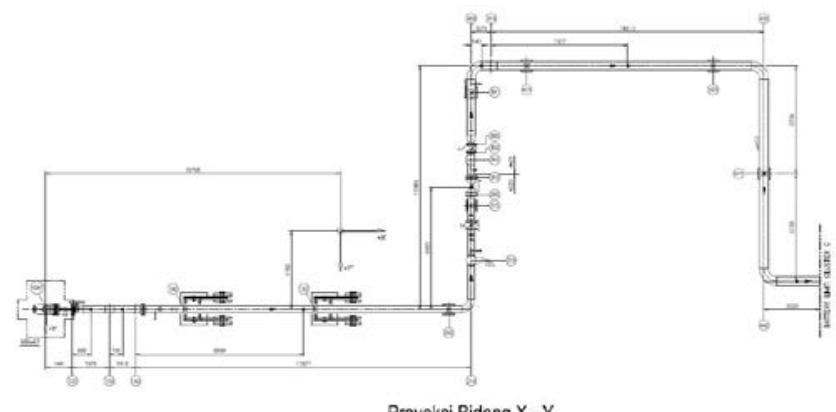

Gambar 3.26. Posisi centeroid sistem perpipaan pada bidang $\mathrm{X}-\mathrm{Y}$

(Sumber: Program AutoCAD 2010)

\section{a. Menentukan Momen Inersia Bidang X-Y (Ixy)}

Tabel 3. Nilai Momen Inersia bidang X-Y

\begin{tabular}{|c|r|r|}
\hline Node & Ixy & \multicolumn{1}{c|}{ Hasil $\left(\mathrm{mm}^{3}\right)$} \\
\hline $10007-150$ & $3417 \times(3288.03) \times(4168.92)$ & 468425298750.00 \\
\hline $150-160$ & $2603 \times(19923.06) \times(4168.92)$ & 216273603113.23 \\
\hline $160-210$ & $17968 \times(29615.06) \times(4168.92)$ & 2218377746591.24 \\
\hline $210-220$ & $2600 \times(15798.06) \times(5468.92)$ & 224635515781.88 \\
\hline $220-280$ & $3514 \times(15798.06) \times(8524.92)$ & 4732555333892.99 \\
\hline $310-350$ & $1359 \times(15798.06) \times(11184.92)$ & 240135310644.22 \\
\hline $380-400$ & $4201 \times(15798.06) \times(15034.42)$ & 997799062840.59 \\
\hline $400-410$ & $3953.30 \times(39138.56) \times(4168.92)$ & 645041632793.66 \\
\hline $410-430$ & $14614 \times(52939.06) \times(4168.92)$ & 3225287611636.19 \\
\hline $430-440$ & $11476 \times(15798.06) \times(22872.92)$ & 4146827091398.06 \\
\hline $440-450$ & $3500 \times(56052.06) \times(4168.92)$ & 817867104423.51 \\
\hline Total & & 13673925511865.60 \\
\hline
\end{tabular}

\section{b. Menentukan Momen Inersia Bidang X-Y Pada Sumbu X (Ix)}

Tabel 4. Nilai Momen Inersia bidang X-Y pada sumbu X

\begin{tabular}{|c|c|c|c|c|c|}
\hline Node & $\mathrm{L}(\mathrm{mm})$ & $\mathrm{X}(\mathrm{mm})$ & $\mathrm{Y}(\mathrm{mm})$ & $\mathrm{Ix}$ & Hasil $\left(\mathrm{mm}^{2}\right)$ \\
\hline $10007-150$ & 3417.00 & 32883.06 & 4168.92 & $\mathrm{LY}^{2}$ & 59386968498.28 \\
\hline $150-160$ & 2603.90 & 19923.06 & 4168.92 & $\mathrm{~L}^{3 / 12+\mathrm{LX}^{2}}$ & 1035033310953.84 \\
\hline $160-210$ & 17968.00 & 29615.06 & 4168.92 & $\mathrm{LY}^{2}$ & 312281255480.59 \\
\hline $210-220$ & 2600.00 & 15798.06 & 5468.92 & $\mathrm{~L}^{3 / 12+\mathrm{LX}^{2}}$ & 650369596078.47 \\
\hline $220-280$ & 3514.00 & 15798.06 & 8524.92 & $\mathrm{~L}^{3 / 12+\mathrm{LX}^{2}}$ & 880635933377.29 \\
\hline $310-350$ & 1359.00 & 15798.06 & 11184.92 & $\mathrm{~L}^{3 / 12+\mathrm{LX}^{2}}$ & 339386774300.42 \\
\hline $380-400$ & 4201.00 & 15798.06 & 15034.42 & $\mathrm{~L}^{3 / 12+\mathrm{LX}^{2}}$ & 1054659029688.16 \\
\hline $400-410$ & 3953.30 & 39138.56 & 4168.92 & $\mathrm{~L}^{3 / 12+\mathrm{LX}^{2}}$ & 6060921073834.77 \\
\hline $410-430$ & 14614.00 & 52939.06 & 4168.92 & $\mathrm{LY}^{2}$ & 253989217920.37 \\
\hline $430-440$ & 11476.00 & 15798.06 & 22872.92 & $\mathrm{~L}^{3 / 12+\mathrm{LX}^{2}}$ & 2990114265077.45 \\
\hline $440-450$ & 3500.00 & 56052.06 & 4168.92 & LY $^{2}$ & 60829496559.55 \\
\hline Total & & & & & 13697606921769.20 \\
\hline
\end{tabular}

\section{c. Menentukan Momen Inersia Bidang X-Y Pada Sumbu Y (Iy)}

Tabel 5. Nilai Momen Inersia bidang X-Y pada sumbu Y

\begin{tabular}{|c|c|c|c|c|c|}
\hline Node & $\bar{L}(\mathrm{~mm})$ & $\overline{\mathrm{X}(\mathrm{mm})}$ & $\mathrm{Y}(\mathrm{mm})$ & Iy & Hasil $\left(\mathrm{mm}^{3}\right)$ \\
\hline $10007-150$ & 3417.00 & 32883.06 & 4168.92 & $\mathrm{~L}^{3} / 12+\mathrm{LY}^{2}$ & 62711677891.03 \\
\hline $150-160$ & 2603.90 & 19923.06 & 4168.92 & $\mathrm{~L}^{3} / 12+\mathrm{LY}^{2}$ & 46726675012.80 \\
\hline $160-210$ & 17968.00 & 29615.06 & 4168.92 & $\mathrm{~L}^{3 / 12+L Y^{2}}$ & 795693860749.92 \\
\hline $210-220$ & 2600.00 & 15798.06 & 5468.92 & $\mathrm{LX}^{2}$ & 648904929411.81 \\
\hline $220-280$ & 3514.00 & 15798.06 & 8524.92 & $\mathrm{LX}^{2}$ & 877019969981.96 \\
\hline $310-350$ & 1359.00 & 15798.06 & 11184.92 & $\mathrm{LX}^{2}$ & 339177615027.17 \\
\hline $380-400$ & 4201.00 & 15798.06 & 15034.42 & $\mathrm{LX}^{2}$ & 1048480618638.08 \\
\hline $400-410$ & 3953.30 & 39138.56 & 4168.92 & $\mathrm{~L}^{3} / 12+\mathrm{L} Y^{2}$ & 73856491092.86 \\
\hline $410-430$ & 14614.00 & 52939.06 & 4168.92 & $\mathrm{~L}^{3 / 12}+\mathrm{L} Y^{2}$ & 514080660215.71 \\
\hline $430-440$ & 11476.00 & 15798.06 & 22872.92 & $\mathrm{LX}^{2}$ & 2864166526896.11 \\
\hline $440-450$ & 3500.00 & 56052.06 & 4168.92 & $\mathrm{~L}^{3 / 12+L Y^{2}}$ & 64402413226.22 \\
\hline Total & & & & & 7335221438143.66 \\
\hline
\end{tabular}

\section{Perhitungan Titik Pusat (centeroid) pada Bidang X-Z}

Tabel 6. Nilai Momen Inersia bidang X-Y pada sumbu $Y$

\begin{tabular}{|c|c|c|c|c|c|}
\hline Node & $\mathrm{L}(\mathrm{mm})$ & $\overline{\mathrm{X}}(\mathrm{mm})$ & L.X' $\left(\mathrm{mm}^{2}\right)$ & $Z^{\prime}(\mathrm{mm})$ & $\mathrm{L} \cdot \mathrm{Z}^{\prime}\left(\mathrm{mm}^{2}\right)$ \\
\hline $10007-150$ & 3417.00 & 17085.00 & 58379445.00 & 0.00 & 0.00 \\
\hline $150-160$ & 2003.00 & 4125.00 & 8262375.00 & -708.00 & 18124.00 \\
\hline $160-210$ & 17968. & 13817.00 & 248263856.00 & 0.00 & 0.00 \\
\hline $210-220$ & 3380. & 0.00 & 0.00 & 0.00 & 0.00 \\
\hline $220-280$ & & 0.00 & & 0.00 & 0.00 \\
\hline $310-350$ & & 0.00 & 0.0 & 0.00 & 0.00 \\
\hline $380-400$ & & 0.00 & & 0.00 & 0.00 \\
\hline $400-410$ & 3041 & 23340.50 & 70978460.50 & -1955.50 & -5946675.50 \\
\hline $410-430$ & 14614 & 37141.00 & 542778574.00 & 0.00 & 0.00 \\
\hline $430-440$ & 14918 & 0.00 & & 0.00 & 0.00 \\
\hline $440-450$ & 3500.00 & 40254.00 & 140889000.00 & 0.00 & 0.00 \\
\hline Total & 74638.00 & & 1069551710.50 & & -7364799.50 \\
\hline
\end{tabular}

Maka posisi titik pusat dari sumbu X-Z adalah:

$\underline{X}=\frac{\sum L X^{i}}{\sum L}=\frac{1069551710,50 \mathrm{~mm}^{2}}{74638,00 \mathrm{~mm}}=14329,85 \mathrm{~mm}\left(\right.$ ke kanan dari sumbu $\left.\mathrm{Z}^{\mathrm{i}}\right)$

$\underline{Z}=\frac{\sum L Z^{i}}{\sum L}=\frac{-7364799,50 \mathrm{~mm}^{2}}{74638,00 \mathrm{~mm}}=-98,67 \mathrm{~mm}\left(\right.$ ke bawah dari sumbu $\left.\mathrm{X}^{\mathrm{i}}\right)$

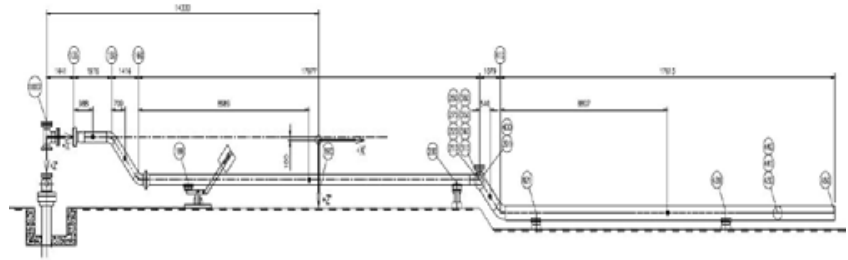

Proyeksi Bidang X-Z 
Gambar 21. Posisi centeroid sistem perpipaan pada bidang X-Z (Sumber : Program AutoCAD 2010)

a. Menentukan Momen Inersia Bidang X-Z (IXz)

Tabel 7. Nilai Momen Inersia bidang X-Z

\begin{tabular}{|c|c|r|}
\hline Node & Ixz & \multicolumn{1}{c|}{ Hasil $\left(\mathrm{mm}^{2}\right)$} \\
\hline $10007-150$ & $3417 \times(31414.85) \times(-98.67)$ & -10592073153.54 \\
\hline $150-160$ & $2003 \times(18454.85) \times(-806.67)$ & -29818749297.01 \\
\hline $160-210$ & $17968 \times(28146.85) \times(-98.67)$ & -49903447342.66 \\
\hline $210-220$ & $3380 \times(14329.85) \times(-98.67)$ & -4779246468.06 \\
\hline $220-280$ & $4568.20 \times(14329.85) \times(-98.67)$ & -6459335418.75 \\
\hline $310-350$ & $1766.70 \times(14329.85) \times(-98.67)$ & -2498075365.42 \\
\hline $380-400$ & $5461.30 \times(14329.85) \times(-98.67)$ & -7722159389.35 \\
\hline $400-410$ & $3041 \times(37670.35) \times(-2054.17)$ & -235316984036.29 \\
\hline $410-430$ & $14614 \times(51470.85) \times(-98.67)$ & -74221789195.34 \\
\hline $430-440$ & $11476 \times(14329.85) \times(-98.67)$ & -21094858641.31 \\
\hline $440-450$ & $3500 \times(54583.85) \times(-98.67)$ & -18850947448.06 \\
\hline Total & & -461257665755.78 \\
\hline
\end{tabular}

b. Menentukan Momen Inersia Bidang $\mathrm{X}-\mathrm{Z}$ Pada Sumbu X (Ix)

Tabel 8. Nilai Momen Inersia bidang X-Z pada sumbu X

\begin{tabular}{|c|c|c|c|c|c|}
\hline Node & (cm) & (mm) & $Z(\mathrm{~mm})$ & Ix & Hassl $\left(\mathrm{mm}^{\prime}\right)$ \\
\hline $0007-150$ & 3417.00 & 31414.85 & -98.67 & $\mathrm{LZ}^{2}$ & 33269543.96 \\
\hline $50-160$ & 2003.0 & 18454.85 & -806.67 & $\mathrm{~L}^{3 / 12+L \mathrm{X}^{2}}$ & 682854 \\
\hline & & & & $\mathrm{LZ}^{2}$ & \\
\hline & 3380.00 & 14329 & & & \\
\hline & 4568.20 & 1432 & -98.67 & $3 / 12+\mathrm{LX}^{2}$ & 946000 \\
\hline & $1 / 66$. & 14329.8 & -98.67 & $\mathrm{~L}^{3 / 12+\mathrm{LX}^{2}}$ & 3632420 \\
\hline & $\frac{\partial 401.50}{30.0}$ & 14729.8 & -98.0 & $\mathrm{~L}^{3 / 12+L X^{2}}$ & 1135023206579.1 \\
\hline $400-410$ & 3041.00 & 37670.3 & 2054.1 & $\mathrm{~L}^{3 / 12+L X^{2}}$ & 4317691713993.6 \\
\hline & 14614. & & -98.67 & $\mathrm{LZ}^{2}$ & 142288883.6 \\
\hline $430-440$ & 14918.80 & 14329.85 & -98.67 & $\mathrm{~L}^{3} / 12+\mathrm{L} \mathrm{X}^{2}$ & 3340204312318.24 \\
\hline $440-450$ & 3500.00 & 54583.85 & -98.67 & $\mathrm{LZ}^{2}$ & 34077671.60 \\
\hline & & & & & \\
\hline
\end{tabular}

c. Menentukan Momen Inersia Bidang $\mathrm{X}-\mathrm{Z}$ Pada Sumbu Z (Iz)

Tabel 9. Nilai Momen Inersia bidang X-Z pada sumbu Z

\begin{tabular}{|c|c|c|c|c|c|}
\hline Node & $\mathrm{L}(\mathrm{mm})$ & $\mathrm{X}(\mathrm{mm})$ & $\mathrm{Z}(\mathrm{mm})$ & $\mathrm{Iz}$ & $\frac{\text { Hasil }\left(\mathrm{mm}^{3}\right)}{3357978936}$ \\
\hline $0007-150$ & 3417.00 & 31414.85 & -98.67 & $\mathrm{~L}^{3 / 12+\mathrm{L} Z^{2}}$ & 3357978936. \\
\hline $150-160$ & & & -806.67 & $\mathrm{LX}^{2}$ & \\
\hline$\frac{160-210}{160}$ & 17968.00 & 28146.85 & -98.67 & $\mathrm{~L}^{3 / 12+\mathrm{L} Z^{2}}$ & 483587550298. \\
\hline $210-220$ & 3380.00 & 14329.85 & -98.67 & $\mathrm{~L}^{3 / 12+L Z^{2}}$ & 3250781960 . \\
\hline $220-280$ & 4568.20 & 14329.85 & -98.67 & $L^{3 / 12+L Z^{2}}$ & 7988749756. \\
\hline $310-350$ & 1766.70 & 14329.85 & -98.67 & $\mathrm{~L}^{3 / 12+L Z^{2}}$ & 476724358. \\
\hline $380-400$ & 5461.30 & 14329.85 & -98.67 & $\mathrm{~L}^{3 / 12+L Z^{2}}$ & 13627142902. \\
\hline $400-410$ & 3041.00 & 37670.35 & 2054.17 & $L X^{2}$ & 4315348197500 \\
\hline $410-430$ & 14614.00 & 51470.85 & -98.67 & $\frac{1+L Z^{2}}{2}$ & 260233731178 \\
\hline $430-440$ & 14918.80 & 14329.85 & -98.67 & $\mathrm{~L}^{3 / 12+L Z^{2}}$ & 276852437346. \\
\hline $440-450$ & 3500.00 & 54583.85 & -98.67 & $\mathrm{~L}^{3 / 12+\mathrm{L} Z^{2}}$ & 3606994338. \\
\hline$T T^{2}$ & & & & & \\
\hline
\end{tabular}

3. Perhitungan Titik Pusat (centeroid) pada Bidang Z-Y

Tabel 10. Penentuan nilai centeroid bidang Z-Y

\begin{tabular}{|c|r|r|r|r|r|}
\hline Node & $\mathrm{L}(\mathrm{mm})$ & $Z(\mathrm{~mm})$ & $\mathrm{L} . Z\left(\mathrm{~mm}^{2}\right)$ & $\mathrm{Y}(\mathrm{mm})$ & \multicolumn{1}{c|}{$\mathrm{L} . \mathrm{Y}^{\prime}\left(\mathrm{mm}^{2}\right)$} \\
\hline $10007-150$ & 4442.10 & 0.00 & 0.00 & 0.00 & 0.00 \\
\hline $150-160$ & 2003.00 & -708.00 & -1418124.00 & 0.00 & 0.00 \\
\hline $120-210$ & 23358.40 & 0.00 & 0.00 & 0.00 & 0.00 \\
\hline $210-220$ & 2600.00 & 0.00 & 0.00 & 1300.00 & 3380000.00 \\
\hline $220-280$ & 3514.00 & 0.00 & 0.00 & 4356.00 & 15306984.00 \\
\hline $310-350$ & 1359.00 & 0.00 & 0.00 & 7016.00 & 9534744.00 \\
\hline $380-400$ & 4201.00 & 0.00 & 0.00 & 10865.50 & 45645965.50 \\
\hline $400-410$ & 3041.00 & -1955.50 & -5946675.50 & 0.00 & 0.00 \\
\hline $410-430$ & 18998.20 & 0.00 & 0.00 & 0.00 & 0.00 \\
\hline $430-440$ & 11476.00 & 0.00 & 0.00 & 18704.00 & 214647104.00 \\
\hline $440-450$ & 4550.00 & 0.00 & 0.00 & 0.00 & 0.00 \\
\hline Total & 79542.70 & & -7364799.50 & & 288514797.50 \\
\hline
\end{tabular}

Maka posisi titik pusat dari sumbu Z-Y adalah:

$\underline{Z}=\frac{\sum L Z^{i}}{\sum L}=\frac{-7364799,50 \mathrm{~mm}^{2}}{79542,70 \mathrm{~mm}}=-92,59 \mathrm{~mm}\left(\right.$ ke bawah dari sumbu $\left.\mathrm{Y}^{\mathrm{i}}\right)$

$\underline{Y}=\frac{\sum L Y^{i}}{\sum L}=\frac{288514797,50 \mathrm{~mm}^{2}}{79542,70 \mathrm{~mm}}=3627,17 \mathrm{~mm}\left(\right.$ ke kanan dari sumbu $\left.\mathrm{Z}^{\mathrm{i}}\right)$

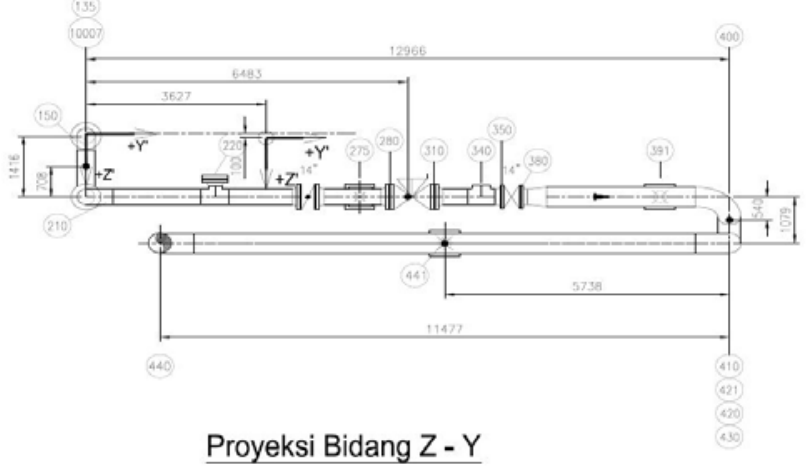

Gambar 22. Posisi centeroid sistem perpipaan pada bidang Z-Y

(Sumber: Program AutoCAD 2010)

\section{a. Menentukan Momen Inersia Bidang Z-Y (Izy)}

Tabel 11. Nilai Momen Inersia bidang Z-Y

\begin{tabular}{|c|r|r|}
\hline Node & Iyz & Hasil $\left(\mathrm{mm}^{3}\right)$ \\
\hline $10007-150$ & $4442.10 \times(3627.17) \times(-92.59)$ & -1491820924.54 \\
\hline $150-160$ & $2003 \times(3627.17) \times(-800.59)$ & -5816456322.49 \\
\hline $160-210$ & $23358.40 \times(3627.17) \times(-92.59)$ & -7844611756.53 \\
\hline $210-220$ & $2600 \times(4927.17) \times(-92.59)$ & -1186127530.08 \\
\hline $220-280$ & $3514 \times(7983.17) \times(-92.59)$ & -2597393009.81 \\
\hline $310-350$ & $1359 \times(10643.17) \times(-92.59)$ & -1339217158.92 \\
\hline $380-400$ & $4201 \times(14492.67) \times(-92.59)$ & -5637176691.96 \\
\hline $400-410$ & $3041 \times(3627.17) \times(-2048.09)$ & -22590875569.51 \\
\hline $410-430$ & $18998.20 \times(3627.17) \times(-92.59)$ & -6380295870.99 \\
\hline $430-440$ & $11476 \times(22331.17) \times(-92.59)$ & -23728079723.97 \\
\hline $440-450$ & $3500 \times(3627.17) \times(-92.59)$ & -1528057721.94 \\
\hline Total & & -78612054558.78 \\
\hline
\end{tabular}

\section{b. Menentukan Momen Inersia Bidang Z-Y Pada Sumbu Z (Iz)}

Tabel 12. Nilai Momen Inersia bidang Z-Y pada sumbu Z 


\begin{tabular}{|c|r|r|r|r|r|}
\hline Node & \multicolumn{1}{|c|}{$\mathrm{L}(\mathrm{mm})$} & \multicolumn{1}{c|}{$\mathrm{Z}(\mathrm{mm})$} & \multicolumn{1}{c|}{$\mathrm{Y}(\mathrm{mm})$} & \multicolumn{1}{c|}{$\mathrm{Iz}$} & \multicolumn{1}{c|}{ Hasil $\left(\mathrm{mm}^{3}\right)$} \\
\hline $10007-150$ & 4442.10 & -92.59 & 3627.17 & $\mathrm{~L}^{3} / 12+\mathrm{LZ}^{2}$ & 7342467639.84 \\
\hline $150-160$ & 2003.00 & -800.59 & 3627.17 & $\mathrm{LY}^{2}$ & 26352175664.60 \\
\hline $160-210$ & 23358.40 & -92.59 & 3627.17 & $\mathrm{~L}^{3} / 12+\mathrm{LZ}^{2}$ & 1062257739979.84 \\
\hline $210-220$ & 2600.00 & -92.59 & 4927.17 & $\mathrm{~L}^{3} / 12+\mathrm{LZ}^{2}$ & 1486955870.04 \\
\hline $220-280$ & 3514.00 & -92.59 & 7983.17 & $\mathrm{~L}^{3} / 12+\mathrm{LZ}^{2}$ & 3646088110.97 \\
\hline $310-350$ & 1359.00 & -92.59 & 10643.17 & $\mathrm{~L}^{3} / 12+\mathrm{LZ}^{2}$ & 220809668.40 \\
\hline $380-400$ & 4201.00 & -92.59 & 14492.67 & $\mathrm{~L}^{3} / 12+\mathrm{LZ}^{2}$ & 6214425259.07 \\
\hline $400-410$ & 3041.00 & -2048.09 & 3627.17 & $\mathrm{LY}^{2}$ & 40008470392.43 \\
\hline $410-430$ & 18998.20 & -92.59 & 3627.17 & $\mathrm{~L}^{3} / 12+\mathrm{LZ}^{2}$ & 571583765931.90 \\
\hline $430-440$ & 11476.00 & -92.59 & 22331.17 & $\mathrm{~L}^{3} / 12+\mathrm{LZ}^{2}$ & 126046119295.92 \\
\hline $440-450$ & 4550.00 & -92.59 & 3627.17 & $\mathrm{~L}^{3} / 12+\mathrm{LZ}^{2}$ & 7888704022.57 \\
\hline Total & \multicolumn{7}{|c}{} & 1853047721835.59 \\
\hline
\end{tabular}

\section{c. Menentukan Momen Inersia Bidang Z-Y} Pada Sumbu Y (Iy)

Tabel 13. Nilai Momen Inersia bidang Z-Y pada sumbu Y

\begin{tabular}{|c|r|r|r|r|r|}
\hline Node & \multicolumn{1}{|c|}{$\mathrm{L}(\mathrm{mm})$} & \multicolumn{1}{c|}{$\mathrm{Z}(\mathrm{mm})$} & \multicolumn{1}{c|}{$\mathrm{Y}(\mathrm{mm})$} & \multicolumn{1}{c|}{ Iy } & \multicolumn{1}{c|}{ Hasil $\left(\mathrm{mm}^{3}\right)$} \\
\hline $10007-150$ & 4442.10 & -92.59 & 3627.17 & $\mathrm{~L}^{3} / 12+\mathrm{LY}^{2}$ & 65746223540.22 \\
\hline $150-160$ & 2003.00 & -800.59 & 3627.17 & $\mathrm{~L}^{3} / 12+\mathrm{LY}^{2}$ & 27021846833.51 \\
\hline $160-210$ & 23358.40 & -92.59 & 3627.17 & $\mathrm{~L}^{3} / 12+\mathrm{LY}^{2}$ & 1369368856754.21 \\
\hline $210-220$ & 2600.00 & -92.59 & 4927.17 & $\mathrm{LZ}^{2}$ & 22289203.37 \\
\hline $220-280$ & 3514.00 & -92.59 & 7983.17 & $\mathrm{LZ}^{2}$ & 30124715.64 \\
\hline $310-350$ & 1359.00 & -92.59 & 10643.17 & $\mathrm{LZ}^{2}$ & 11650395.15 \\
\hline $380-400$ & 4201.00 & -92.59 & 14492.67 & $\mathrm{LZ}^{2}$ & 36014208.99 \\
\hline $400-410$ & 3041.00 & -2048.09 & 3627.17 & $\mathrm{~L}^{3} / 12+\mathrm{LY}^{2}$ & 42351986885.85 \\
\hline $410-430$ & 18998.20 & -92.59 & 3627.17 & $\mathrm{~L}^{3} / 12+\mathrm{LY}^{2}$ & 821367930031.45 \\
\hline $430-440$ & 11476.00 & -92.59 & 22331.17 & $\mathrm{LZ}^{2}$ & 98381114.59 \\
\hline $440-450$ & 4550.00 & -92.59 & 3627.17 & $\mathrm{~L}^{3} / 12+\mathrm{LY}^{2}$ & 67711105442.33 \\
\hline Total & \multicolumn{7}{|c}{} & & 2393766409125.31 \\
\hline
\end{tabular}

Dari hasil perhitungan diatas didapat disimpulkan nilai momen inersia pada sistem perpipaan yang diproyeksikan pada bidang $\mathrm{X}-\mathrm{Y}, \mathrm{X}-\mathrm{Z}$, dan Z-Y adalah sebagai berikut:

- Momen inersia bidang X-Y (Ixy): $13673925511865,60 \mathrm{~mm}^{3}$

- M omen inersia bidang X-Z (Ixz): 461257665755,78 $\mathrm{mm}^{3}$

- $\quad$ M omen inersia bidang Y-Z (Iyz): $78612054558,78 \mathrm{~mm}^{3}$

Sedangkan untuk momen inersia pada 3 sumbu $X$, Y, dan Z dari perhitungan di atas diperoleh:

- $\mathrm{M}$ omen inersia terhadap sumbu X (Ix): 25180290788894,10 $\mathrm{mm}^{3}$

- Momen inersia terhadap sumbu Y (Iy): 9728987847268,97 $\mathrm{mm}^{3}$

- Momen inersia terhadap sumbu Z (Iz): $7903563094650,53 \mathrm{~mm}^{3}$

- Momen inersia I: 240669866,29 $\mathrm{mm}^{4}$

- Panjang total pipa yang berada searah dengan sumbu X $(L x)=42003 \mathrm{~mm}$

- Panjang total pipa yang berada searah dengan sumbu Y $(L y)=24442 \mathrm{~mm}$

- Panjang total pipa yang berada searah dengan sumbu Z $(L z)=2495 \mathrm{~mm}$

\section{Perhitungan Pertambahan Panjang Pipa Pada Sumbu X, Y, Z}

Pertambahan panjang pada sumbu $X$
$\Delta x=\frac{\alpha}{1200 \mathrm{in}} \times L x=129,36 \mathrm{~mm}$

$\Delta x . E . I=129,36 \mathrm{~mm} \times 20682 \mathrm{~kg} / \mathrm{mm}^{2} \times 240669866,28 \mathrm{~mm}^{4}$

$=643939813216538 \mathrm{~kg} \cdot \mathrm{mm}^{3}$

Pertambahan panjang pada sumbu $Y$

$\Delta y=\frac{\alpha}{1200 \text { in }} \times L y=75,28 \mathrm{~mm}$

$\Delta y . E . I=75,28 \mathrm{~mm} \times 20682 \mathrm{~kg} / \mathrm{mm}^{2} \times 240669866,28 \mathrm{~mm}^{4}$

$=374715542095532 \mathrm{~kg} \cdot \mathrm{mm}^{3}$

Pertambahan panjang pada sumbu $\mathrm{Z}$

$\Delta z=\frac{\alpha}{1200 \text { in }} \times L z=7,68 \mathrm{~mm}$

$\Delta z . E . I=7,68 \mathrm{~mm} \times 20682 \mathrm{~kg} / \mathrm{mm}^{2} \times 240669866,28 \mathrm{~mm}^{4}$

$=38250359116617 \mathrm{~kg} \cdot \mathrm{mm}^{3}$

\section{Perhitungan Gaya yang Bekerja Pada Sumbu X,Y,Z}

Maka untuk menemukan jumlah gaya yang bekerja pada sumbu $\mathrm{X}, \mathrm{Y}$, dan $\mathrm{Z}$ di gunakan metode eliminasi dan subsitusi, di bawah ini hasil perhitungannya.

Besar gaya pada sumbu $X=30,76 \mathrm{~kg}$ Besar gaya pada sumbu $\mathrm{Y}=79,43 \mathrm{~kg}$ Besar gaya pada sumbu $Z=19,32 \mathrm{~kg}$

Tabel 14. Nilai Momen Tekuk dan Momen Torsi pada node 149

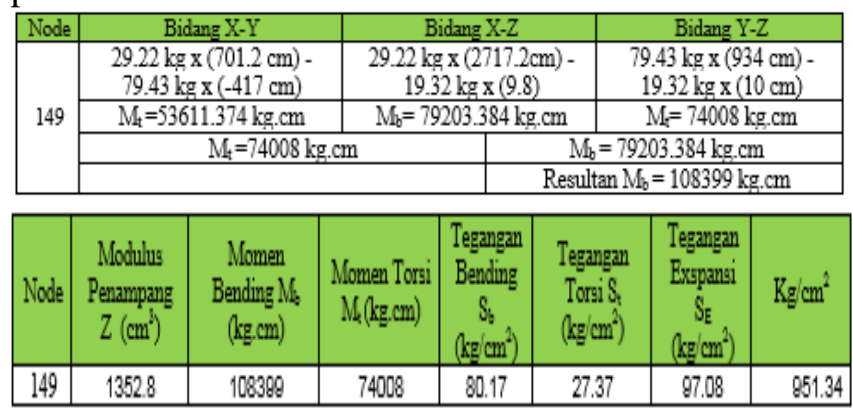

\section{Simulasi Tegangan Pipa Akibat Beban Sustain dengan Software CAESAR II}

Pada software CAESAR II untuk tegangan pipa akibat ekspansi terdapat pada node 149 dan besarnya pun dapat dilihat seperti ditunjukan pada gambar 24 dibawah ini.

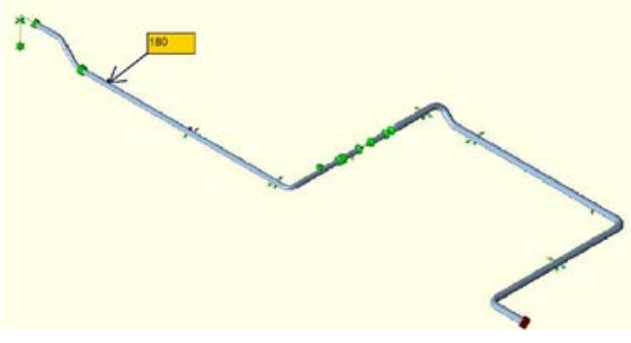




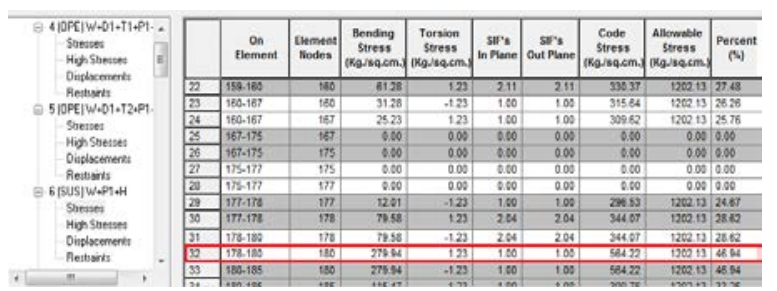

Gambar 23. Posisi Node 180

Untuk hasil setelah program dirunning maka dapat dilihat besarnya tegangan sustain yang terdapat pada node 180 seperti gambar 24. dibawah ini.

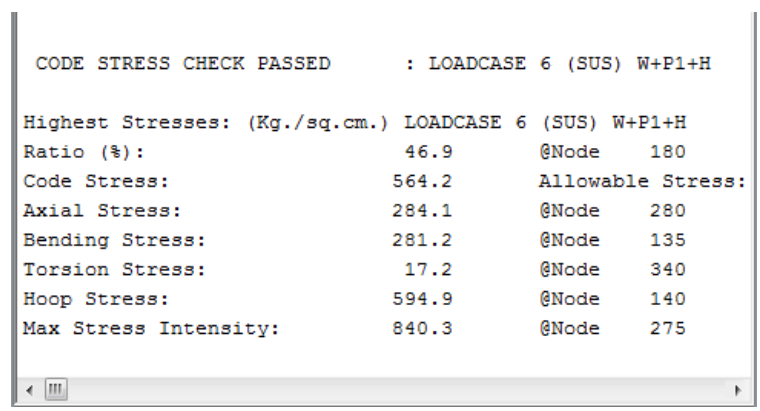

Gambar 23. Besaran Tegangan Sustain

\section{Simulasi Tegangan Pipa Akibat Beban Ekspansi dengan Software CAESAR II}

Pada software CAESAR II untuk tegangan pipa akibat ekspansi terdapat pada node 149 dan besarnya pun dapat dilihat seperti ditunjukan pada gambar 24 dibawah ini.

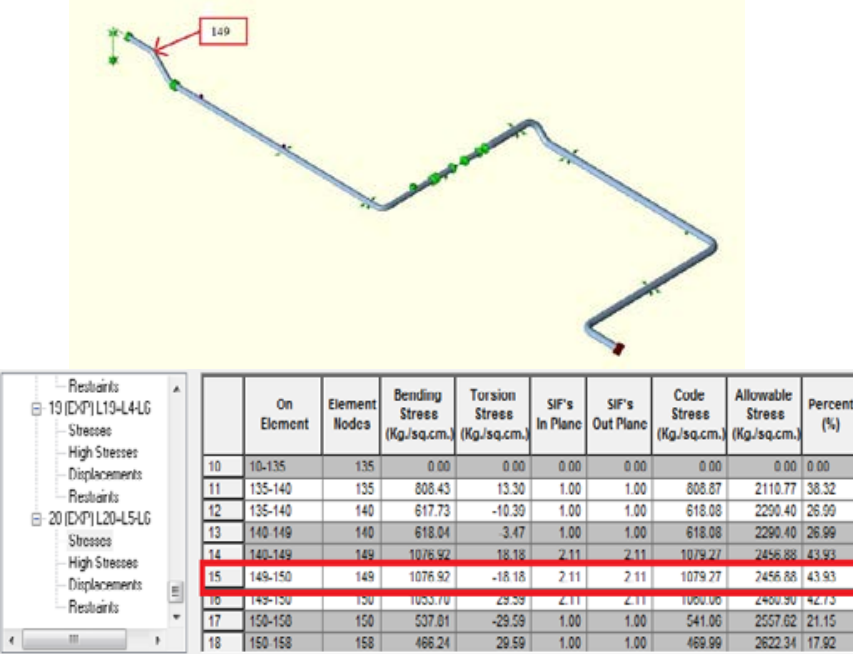

Gambar 24. Ekspansi Node 149

Untuk hasil setelah program dirunning maka dapat dilihat besarnya tegangan sustain yang terdapat pada node 180 seperti gambar 25 dibawah ini.

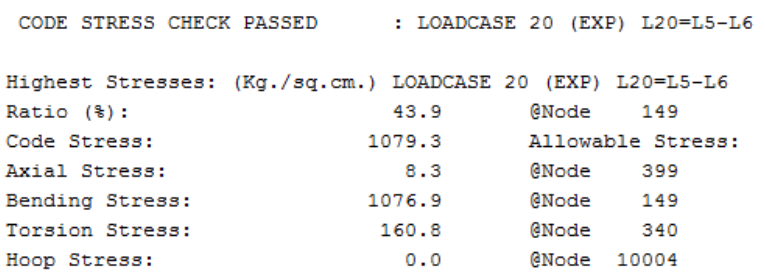

Gambar 25. Tegangan Sustain Node 180

\section{ANALISIS DAN PEMBAHASAN}

\subsection{Evaluasi Perhitungan Tegangan Pipa dengan Program CAESAR II}

Dalam melakukan perhitungan dengan program CAESAR II didapat hasil output gaya, momen dan tegangan pipa pada saat sistem beroperasi, yang besarnya bervariasi sesuai dengan jenis material yang digunakan, besar temperatur, tekanan dan tingkat fleksibilitas jalur tersebut. Jadi tegangan maksimum hasil output perhitungan kalkulasi program CAESAR II pada tegangan Sustain \& Ekspansi di bawah ini.

Tabel 15. Nilai tegangan pada pipa 0C27LBA0114”-AD20 BR001, 0C27LBA01-14”-AA20 BR005 dan 0CSGLBA01-18”-AA20 BR00

\begin{tabular}{|l|c|c|c|c|}
\hline \multicolumn{1}{|c|}{ Load Case } & Node & $\begin{array}{c}\text { Calculation } \\
\text { Stress } \\
\left(\mathrm{Kg} / \mathrm{cm}^{2}\right)\end{array}$ & $\begin{array}{c}\text { Allowable } \\
\text { Stress } \\
\left(\mathrm{Kg} / \mathrm{cm}^{2}\right)\end{array}$ & $\begin{array}{c}\text { Ratio } \\
(\%)\end{array}$ \\
\hline 1 (HYD) WW+HP+H & 275 & 563.3 & 2214.4 & 25.4 \\
\hline 2 (SUS) W+P1+H & 135 & 611.5 & 1202.1 & 50.9 \\
\hline 4 (EXP) L19=L4-L6 & 149 & 1224.1 & 2519 & 48.6 \\
\hline 5 (EXP) L20=L5-L6 & 149 & 1213.9 & 2519 & 48.2 \\
\hline
\end{tabular}

\subsection{Evaluasi Perhitungan Tegangan Pipa Akibat Beban Sustain pada Program CAESAR II dan Perhitungan Manual}

Berdasarkan acuan standar ASME B31.1, besar dan titik terjadinya tegangan maksimum sistem perpipaan akibat beban sustain pada program CAESAR II seperti terlihat pada Tabel 16 dibawah ini.

Tabel 16. Nilai tegangan akibat Beban Sustain CAESAR II

\begin{tabular}{|c|c|c|c|c|c|}
\hline Node & $\begin{array}{c}\text { Bending } \\
\text { Stress } \\
\left(\mathrm{Kg} \mathrm{cm}^{2}\right)\end{array}$ & $\begin{array}{c}\text { Torsion Stress } \\
\left(\mathrm{Kg} / \mathrm{cm}^{2}\right)\end{array}$ & $\begin{array}{c}\text { Sustained } \\
\text { Load } \\
\left(\mathrm{Kg} \mathrm{cm}^{2}\right)\end{array}$ & $\begin{array}{c}\text { Allowrable } \\
\text { Stress } \\
\left(\mathrm{Kg} \mathrm{cm}^{2}\right)\end{array}$ & Ratio (\%) \\
\hline 180 & 281.2 & 17.2 & 564.2 & 1202.1 & 46.9 \\
\hline
\end{tabular}

Dari hasil perhitungan manual yang telah dijelaskan sebelumnya, maka diperoleh nilai tegangan maksimum akibat beban ekspansi. Seperti terlihat pada Tabel 17 dibawah ini merupakan perbandingan antara hasil perhitungan tegangan 
ekspansi program CAESAR II dengan perhitungan manual.

Tabel 17. Perbandingan nilai Tegangan Maksimum Beban Sustain Program CAESAR II dengan Perhitungan Manual

\begin{tabular}{|c|c|c|c|c|c|}
\hline Node & $\begin{array}{l}\text { Program } \\
\text { CAESAR I } \\
\left(\mathrm{Kg} / \mathrm{cm}^{2}\right)\end{array}$ & $\begin{array}{c}\text { Perhitungar } \\
\text { Manual } \\
\left(\mathrm{Kg} / \mathrm{cm}^{2}\right)\end{array}$ & $\begin{array}{c}\text { Deviasi } \\
\text { Perhitungan } \\
(\%)\end{array}$ & $\begin{array}{l}\text { Allowable } \\
\text { Stress } \\
\left(\mathrm{Kg} / \mathrm{cm}^{2}\right)\end{array}$ & Status \\
\hline 180 & 564.2 & 327.3 & $41.99 \%$ & 1202.1 & $\mathrm{OK}$ \\
\hline Node & $\begin{array}{c}\text { Program } \\
\text { CAESAR } \\
\text { II }\left(\mathrm{Kg} / \mathrm{cm}^{2}\right)\end{array}$ & $\begin{array}{c}\text { Perhitungan } \\
\text { Manual } \\
\left(\mathrm{Kg} / \mathrm{cm}^{2}\right)\end{array}$ & $\begin{array}{c}\text { Deviasi } \\
\text { Perhitungan } \\
\left(\mathrm{Kg} / \mathrm{cm}^{2}\right)\end{array}$ & $\begin{array}{l}\text { Allowable } \\
\text { Stress } \\
\left(\mathrm{Kg}^{\prime} \mathrm{cm}^{2}\right)\end{array}$ & Status \\
\hline 180 & 564.2 & 327.3 & 236.9 & 1202.1 & $\mathrm{OK}$ \\
\hline
\end{tabular}

Secara keseluruhan nilai tegangan akibat beban sustain tidak melebihi batas tegangan izin dari standar ASME B31.1 sebesar 1202,1 Kg/cm2. Terjadinya deviasi perbedaan nilai tersebut dikarenakan pada program CAESAR II perhitungan gaya serta momen dilakukan dengan metode finite element sehingga mampu menghitung lebih mendetail, sedangkan pada perhitungan manual menggunakan teori-teori perhitungan yang bersifat umum.

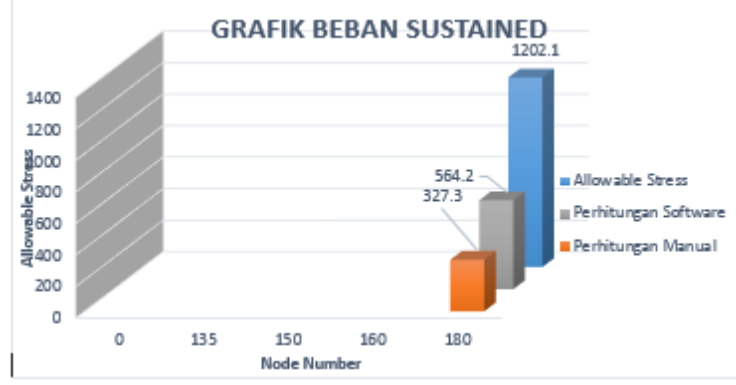

Gambar 26. Grafik perbandingan nilai Sustained load manual dan Software (Sumber : Program Office 2013)

\subsection{Evaluasi Perhitungan Tegangan Pipa Akibat Beban Ekspansi pada Program CAESAR dan Perhitungan Manual}

Berdasarkan acuan standar ASME B31.1, besar dan titik terjadinya tegangan maksimum pada sistem perpipaan akibat beban ekpansi pada program CAESAR seperti terlihat pada Tabel 18 dibawah ini.

Tabel 18. Nilai tegangan akibat Beban Ekspansi CAESAR II

\begin{tabular}{|c|c|c|c|c|c|}
\hline Node & $\mid \begin{array}{c}\text { Bending Stress } \\
\left(\mathrm{Kg} \mathrm{cm}^{2}\right)\end{array}$ & $\begin{array}{c}\text { Torsion Stress } \\
\left(\mathrm{Kg} / \mathrm{cm}^{2}\right)\end{array}$ & $\begin{array}{l}\text { Expansion } \\
\operatorname{Load}\left(\mathrm{Kg}_{\mathrm{cm}} \mathrm{mm}^{2}\right)\end{array}$ & $\begin{array}{l}\text { Allowable } \\
\text { Stress } \\
\left(\mathrm{Kg}^{2} \mathrm{~m}^{2}\right)\end{array}$ & $\operatorname{Ratio}(\%)$ \\
\hline 149 & 1076.9 & 1600.8 & 1079.3 & 2456.9 & 43.9 \\
\hline
\end{tabular}

Dari hasil perhitungan manual yang telah dijelaskan sebelumnya, maka diperoleh nilai tegangan maksimum akibat beban ekspansi. Seperti terlihat pada Tabel 19 dibawah ini merupakan perbandingan antara hasil perhitungan tegangan ekspansi program CAESAR II dengan perhitungan manual.

Tabel 19. Perbandingan Nilai Tegangan Maksimum Beban Ekspansi Program CAESAR II dengan Perhitungan Manual

\begin{tabular}{|c|c|c|c|c|c|}
\hline Node & $\begin{array}{c}\text { Program } \\
\text { CAESAR II } \\
\left(\mathrm{Kg} / \mathrm{cm}^{2}\right)\end{array}$ & $\begin{array}{c}\text { Perhitungan } \\
\text { Manual } \\
\left(\mathrm{Kg} / \mathrm{cm}^{2}\right)\end{array}$ & $\begin{array}{c}\text { Deviasi } \\
\text { Perhitungan } \\
(\%)\end{array}$ & $\begin{array}{c}\text { Allowable } \\
\text { Stress } \\
\left(\mathrm{Kg} / \mathrm{cm}^{2}\right)\end{array}$ & Status \\
\hline 149 & 1079.3 & 951.34 & $11.86 \%$ & 2456.9 & OK \\
\hline \multicolumn{7}{|c|}{ Node } & $\begin{array}{c}\text { Program } \\
\text { CAESAR } \\
\left.\text { II }\left(\mathrm{Kg}_{\mathrm{cm}}\right)^{2}\right)\end{array}$ & $\begin{array}{c}\text { Perhitungan } \\
\text { Manual } \\
\left(\mathrm{Kg} / \mathrm{cm}^{2}\right)\end{array}$ & $\begin{array}{c}\text { Deviasi } \\
\text { Perhitungan } \\
\left(\mathrm{Kg} / \mathrm{cm}^{2}\right)\end{array}$ & $\begin{array}{c}\text { Allowable } \\
\text { Stress } \\
\left(\mathrm{Kg}^{2} \mathrm{~cm}^{2}\right)\end{array}$ & Status \\
\hline 149 & 1079.3 & 951.34 & 127.96 & 2456.9 & OK \\
\hline
\end{tabular}

Besarnya tegangan akibat beban ekspansi pada node 149 dari hasil perhitungan Program CAESAR II adalah sebesar 1079,3 Kg/cm2 dan dari hasil perhitungan Manual adalah sebesar 791 $\mathrm{Kg} / \mathrm{cm} 2$ dengan deviasi perhitungan dari kedua metode tersebut adalah 26,71\%, dimana tegangan yang terjadi pada sistem tidak melebihi batasan yang ditetapkan oleh standar sehingga sistem perpipaan dinyatakan dalam batas aman untuk beroperasi.

Secara keseluruhan nilai tegangan akibat beban ekspansi tidak melebihi batas tegangan yang diizinkan oleh material dari standar ASME B31.1 sebesar 2456,9 Kg/cm2. Terjadinya deviasi perbedaan nilai tersebut dikarenakan pada program CAESAR II perhitungan gaya serta momen dilakukan dengan metode finite element sehingga mampu menghitung lebih mendetail, sedangkan pada perhitungan manual menggunakan teori-teori perhitungan yang bersifat umum.

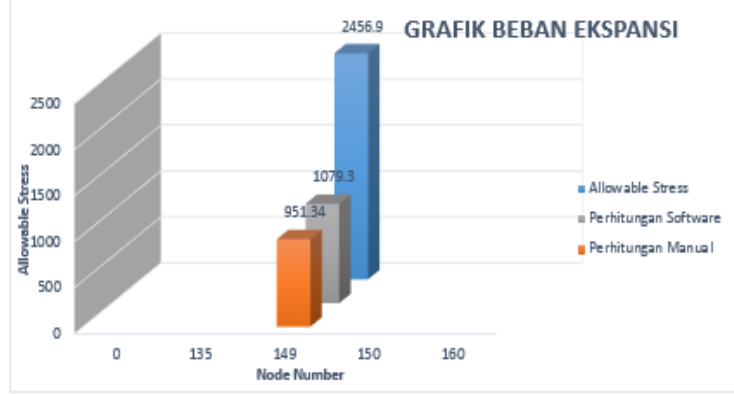

Gambar 27. Grafik perbandingan nilai Ekspansi load manual dan Software (Sumber : Program Office 2013)

\section{KESIMPULAN}

Berdasarkan hasil perhitungan tegangan pada sistem perpipaan Line 0C27LBA01-14"AD20BR001, 0C27LBA01-14"-AA20 BR005 dan 0CSGLBA01-18”-AA20 BR001 dapat disimpulkan sebagai berikut:

1. Nilai tegangan yang diakibatkan beban Sustain (SL) yang tertinggi baik dari hasil perhitungan 
program CAESAR II ataupun perhitungan Manual terjadi pada node 180 . Yaitu sebesar $564,2 \mathrm{Kg} / \mathrm{cm} 2$ (CAESAR II) dan 327,3 Kg/cm2 (Perhitungan Manual). Dari hasil perhitungan secara keseluruhan nilai tegangan akibat beban sustain tidak melebihi batas tegangan izin dari standar ASME B31.1 yaitu sebesar 1202,1 $\mathrm{Kg} / \mathrm{cm} 2$ sehingga sistem perpipaan dinyatakan dalam batas aman untuk beroperasi.

2. Nilai tegangan yang diakibatkan beban Ekspansi (SE) yang tertinggi baik dari hasil perhitungan program CAESAR II ataupun perhitungan Manual terjadi pada node 149. Yaitu sebesar 1079,3 Kg/cm2 (CAESAR II) dan 951,34 $\mathrm{Kg} / \mathrm{cm} 2$ (Perhitungan Manual) dari hasil perhitungan secara keseluruhan nilai tegangan akibat beban ekspansi tidak melebihi batas tegangan yang diizinkan oleh material dari standar ASME B31.1 sebesar 2456,9 Kg/cm2 sehingga sistem perpipaan dinyatakan dalam batas aman untuk beroperasi. dalam batas aman untuk beroperasi.

3. Deviasi hasil perhitugan maksimum dari dari tegangan akibat beban Sustain antara perhitungan program CAESAR II dan perhitungan manual sebesar 236,9 $\mathrm{Kg} / \mathrm{cm} 2$ atau sebesar 41,99\%.

4. Deviasi hasil perhitugan maksimum dari dari tegangan akibat beban Ekspansi Thermal antara perhitungan program CAESAR II dan perhitungan manual sebesar $127,96 \mathrm{Kg} / \mathrm{cm} 2$ atau sebesar $11,86 \%$.

5. Akibat fluktuasi fluida setiap harinya maka perlu tambahan support untuk bisa menahannya dan penambahan suuport pada diletakan pada node 180 dan type support yang digunakan adalah type yang fleksible sehingga bisa mengikutin pergerakan pipa yang berubah-ubah.

6. Setelah dilakukan perhitungan ulang, dari segi penggunaan material design dapat di reduce menjadi 12 inch dan sistem perpipaan tetap aman pada saat beroperasi.

\section{DAFTAR PUSTAKA}

Agustinus, Donny, Pengantar Piping Stress Analysis dengan Caesar II. Jakarta: Entry Augustino Publisher, 2009

Tri Adi Siswanto, Hari Prastowo, dan Beni Cahyono, 2014, Tegangan Pipa: Analisa Pengaruh Water Hamer Terhadap Nilai Stress Pipa Pada Sistem Loading-Offloading PT. DABN, Surabaya: JURNAL TEKNIK POMITS, Vol.3, No.1: hal.142-148

Raswari, Perencanaan Dan Penggambaran Sistem perpipaan, Penerbit Universitas Indonesia, UI - Press, Jakarta, 2007.
Dahlan, Dahmir. 2016. Analisis Tegangan Perpipaan. Jakarta: Sekolah Pascasarjana ISTN

Liang - Chuan (L.C.) Peng, and Tsen Loong (Alvin) Peng, Pipe Stress Engineering, Peng Engineering, ASME Press, New York, 2009.

Manurung, P., Syam, B. 2013, Analisa Tegangan Perpipaan: ANALISA TEGANGAN PIPA PADA SISTEM PERPIPAAN HEAVY FUEL OIL DARI TANK UNIT 1 DAN UNIT 2 MENUJU HEAT EXCHANGRE DI PLTU BELAWAN, Medan: Jurnal e-Dinamis, Vol.5, No.1: hal. 37-46

American Society of Mechanical Engineers. ASME B31.1, Power Piping. ASME International. 2012.

Rhea, Robert. A and Parisher, Roy, Pipe Drafting and Design, Second Edition, Gulf Profesional Publishing, 2002.

Jamaludin, Achmad, 2016, Analisis Tegangan Sistem Perpipaan Pada Sisi Tekan Pompa P003E Menggunakan Caesar 2 dan Perhitungan Manual, Jurusan Teknik Mesin, Institut Sains dan Teknologi Nasional, Jakarta.

ITT Grinnell Industrial Piping, Piping Design and Engineering, $7^{\text {th }}$ Edition, Inc., ITT Grinnell Corporation, USA, 1995.

Proyek X. Job Notes for Piping Material. Jakarta: PT X, 2014.

Proyek X. Job Notes for Piping Stress Analysis Spesification. Jakarta: PT X, 2014. 